\title{
Chemical Mechanisms of ${ }^{60} \mathrm{Co}$
} Transport in Ground Water from Intermediate-Level Liquid Waste Trench 7: Progress Report for Period Ending June 30, 1975
J. L. Means
D. A. Crerar
J. O. Duguid

Environmental Sciences Division

Publication No. 940

\section{OAK RIDGE NATIONAL LABORATORY}




\section{DISCLAIMER}

This report was prepared as an account of work sponsored by an agency of the United States Government. Neither the United States Government nor any agency Thereof, nor any of their employees, makes any warranty, express or implied, or assumes any legal liability or responsibility for the accuracy, completeness, or usefulness of any information, apparatus, product, or process disclosed, or represents that its use would not infringe privately owned rights. Reference herein to any specific commercial product, process, or service by trade name, trademark, manufacturer, or otherwise does not necessarily constitute or imply its endorsement, recommendation, or favoring by the United States Government or any agency thereof. The views and opinions of authors expressed herein do not necessarily state or reflect those of the United States Government or any agency thereof. 


\section{DISCLAIMER}

Portions of this document may be illegible in electronic image products. Images are produced from the best available original document. 


\section{Printed in the United States of America. Available from National Technical Information Service \\ U.S. Department of Commerce \\ 5285 Port Royal Road, Springfield, Virginia 22161 \\ Price: Printed Copy $\$ 4,50$; Microfiche $\$ 3.00$}

This report was prepared as an account of work sponsored by the United States Government. Neither the United States nor the Energy Research and Development Administration/United States Nuclear Regulatory Commission, nor any of their employees, nor any of their contractors, subcontractors, or their employees, makes any warranty, express or implied, or assumes any legal liability or responsibility for the accuracy, completeness or usefulness of any information, apparatus, product or process disclosed, or represents that its use would not infringe privately owned rights. 
ORNL/TM-5348

Distribution category UC-70

Contract No. W-7405-eng-26

CHEMICAL MECHANISMS OF ${ }^{60}$ CO TRANSPORT IN GROUND WATER FROM INTERMEDIATE-LEVEL LIQUID WASTE TRENCH 7: PROGRESS REPORT FOR PERIOD ENDING JUNE 30, 1975

\author{
J. L. Means, D. A. Crerar, \\ Dept. of Geophysical and Geological Sciences \\ Princeton University \\ Princeton, New Jersey \\ and \\ J. 0. Duguid \\ Environmental Sciences Division
}

Environmental Sciences Division

Publication No. 940

Date Published: November 1976

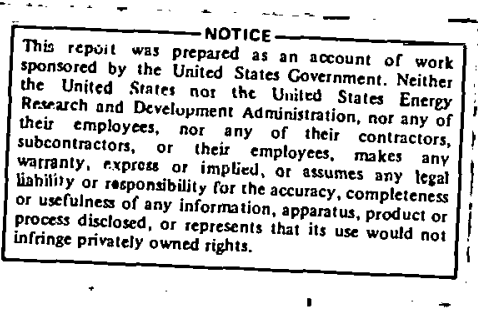

OAK RIDGE NATIONAL LABORATORY

Oak Ridge, Tennessee 37830

operated by

UNION CARBIDE CORPORATION

for the

ENERGY RESEARCH AND DEVELOPMENT ADMINISTRATION 
THIS PAGE

WAS INTENTIONALLY

LEFT BLANK 


\section{ACKNOWLEDGMENTS}

The authors wish to thank E. A. Bondietti and Tsuneo Tamura for their analyses and observations which aided in determining conditions and transport mechanisms near trench 7 . Special thanks are also extended to 0. M. Sealand for his aid in the field work and in the maintenance of an efficient field and laboratory study. 


\section{THIS PAGE}

WAS INTENTIONALLY

LEFT BLANK 


\begin{abstract}
MEANS, J. L., D. A. CRERAR, and J. 0. DUGUID. 1976. Chemical mechanisms of ${ }^{60} \mathrm{Co}$ transport in ground water from intermediate-level 1iquid waste trench 7: Progress report for period ending June 30, 1975. ORNL/TM-5348. Oak Ridge National Laboratory, Oak Ridge, Tennessee. pp.
\end{abstract}

A seep approximately 50 meters east of trench 7 within the ORNL restricted area contains ${ }^{60} \mathrm{Co}$ in concentrations of $10^{4}$ to $10^{6} \mathrm{dpm} / \mathrm{g}$ in the soil and $10^{3} \mathrm{dpm} / \mathrm{ml}$ in the water. Traces of ${ }^{125} \mathrm{Sb}$ and various transuranics have also been detected in the soll. However, because the volume of water discharge from the seep is small, the total radionuclide contribution from the trench 7 area to White Oak Creek and the Clinch River is insignificant.

The ${ }^{60} \mathrm{Co}$ is transported in the ground-water from the trench to the seep as organic complexes and is absorbed by manganese oxides and to a lesser extent by iron sesquioxides in the shale and soll. In the absence of these organic complexing agents, ${ }^{60} \mathrm{Co}$ mobilization would be negligible because the sediment absorption capacity for inorganic forms of $6{ }^{\circ} \mathrm{Co}$ is extremely high.

The primary objective of this study has been to investigate ${ }^{60} \mathrm{Co}$ transport and absorption mechanisms as observed in the study area. Because the organic complexing characteristics of transition metals and transuranics are similar, the mechanisms of ${ }^{60} \mathrm{Co}$ transport determined in this study may also apply to plutonium and other alpha-emitters. Also the experimental and analytical methods employed in this study apply to the identification of other migrating radionuclide complexes from other disposal trenches and pits at ORNL. The increased knowledge of transport and adsorption mechanisms will provide insight into methods of controlling the movement of radionuclides from these and future disposal areas. 
THIS PAGE

\section{WAS INTENTIONALLY \\ LEFT BLANK}


TABLE OF CONTENTS

$\underline{\text { Page }}$

ACKNOWLEDGMENTS .......................... . . . . . . . .

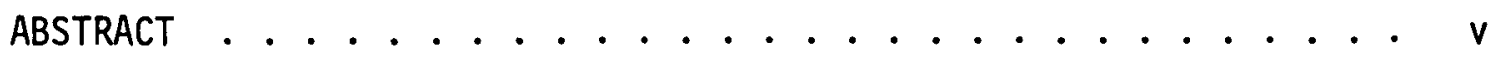

LIST OF TABLES .................... . . . $\mathrm{ix}$

LIST OF FIGURES . . . . . . . . . . . . . . . xi

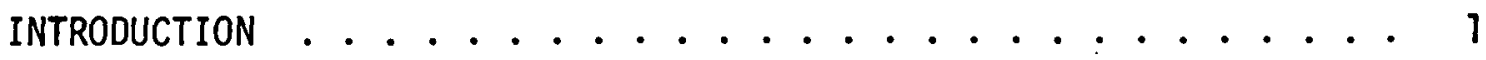

GROUND-WATER QUALITY NEAR TRENCH $7 \ldots \ldots \ldots$

Radionuclide Content ........... 3

Nonradioactive Constituents ........... 11

Field Measurement of pH, Eh, and Temperature . . . . . 15

COBALT-60 TRANSPORT MECHANISMS ................... 16

Cation Exchange Resin Data.......... 16

Potentiometric Titration Results . . . . . . . . 18

Natural Organic Acids as Trace Metal Complexes: Background . 18

Molecular Weight of Organics from Dialysis ....... 19

Molecular Weight of Organics from Gel Chromatography . . . . 19

Application of the Computer Program WATEQ . . . . . 20

COBALT-60 ADSORPTION MECHANISMS ............... 23

Spiked Seep Water--Shale Adsorption Experiment . . . . . . 24

Concentration of ${ }^{60}$ Co Related to Soil Particle Size . . . . 25

Adsorption by $\mathrm{MnO}_{2}$, Fe Sesquioxides, and Insoluble Organics . 25 CONCLUSIONS . . . . . . . . . . . . . . . . 27

REFERENCES .......................... 28

APPENDIX: Content of ${ }^{60}$ Co in Shale and Soir ......... 31 
THIS PAGE

\section{WAS INTENTIONALLY LEFT BLANK}




\section{LIST OF TABLES}

Table

Page

1 Radionuclide analyses of water samples from wells near trench $7(\mathrm{dpm} / \mathrm{ml})$. . . . . . . . . . . . . . . . . 5

2 Field $\mathrm{pH}$, temperature, total alkalinity, and dissolved $\mathrm{Ca}^{2+}$ of water samples collected near trench 7 (June 1975) . . 17

Al Cobalt-60 concentration and pH of shale from wells drilled between trench 7 and cobalt seep (June 1974) . . . . . . 32

A2 Cobalt-60 concentration, total- $\alpha$ concentration, and $\mathrm{pH}$ of soils from wells drilled near the cobalt seep (June-August

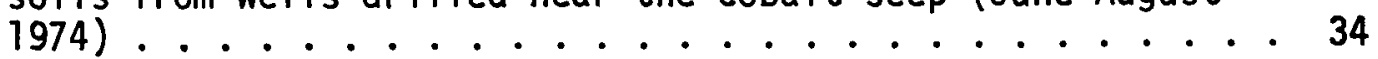




\section{THIS PAGE}

\section{WAS INTENTIONALLY LEFT BLANK}




\section{LIST OF FIGURES}

Figure

Page

$1 \quad$ Location of small seeps associated with seepage pits 1 , 2,3 , and 4 and trenches 5,6 , and $7 \ldots 2$

2 Location of wells near trench 7 ......... 4

3 Location of wells and the cobalt seep, the approximate ${ }^{60} \mathrm{Co}$ concentration in $\mathrm{dpm} / \mathrm{ml}$ (1974 data), and the probable direction of ground-water flow .........

4 Location of wells and the cobalt seep, the approximate concentration of ${ }^{3} \mathrm{H}$, in $\mathrm{dpm} / \mathrm{ml}$ (1974 data), and the probable direction of ground-water flow ...... 10

5 Concentration of $\mathrm{Na}^{+}, \mathrm{NO}_{3}{ }^{-}$, and $\mathrm{SO}_{4}{ }^{2}$-versus ${ }^{60} \mathrm{Co}$ in. we11 and seep water near trench 7 (August 1974) .... 13

6 Concentration of $\mathrm{Na}^{+}, \mathrm{NO}_{3}{ }^{-}$, and $\mathrm{SO}_{4}{ }^{2}$-versus ${ }^{60} \mathrm{Co}$ in well and seep water near trench 7 (June 1975) ..... 14

7 Cobalt-60 concentration in relation to particle size in four samples from the soll profile near the cobalt seep

8 Elution profiles of water samples from well T7-3 and the cobalt seep ................

9 Percent of clay, silt, and sand in four samples from the soll profile near the cobalt seep .......... 


\section{INTRODUCTION}

Since the beginning of operations at ORNL, soils have been used for the disposal of radioactive waste. Disposal consisted of land burial of solid waste in unlined trenches that were covered with soil or concrete. Based on this experience and with the knowledge that the Conasauga shale is somewhat impermeable, the construction of pits for disposal of intermediate-level liquid waste was begun in 1951 (Fig. 1). The first experimental pit, pit 1, was opened in 1951 and closed almost immediately because of breakthrough of radionuclides due to the pit's poor location. A second pit, pit 2, was brought into operation in 1952, and for the first time large quantities of intermediate-level waste were discharged into terrestrial pits. Pits 3 and 4 became operational in 1955 and 1956, respectively. The first covered trench, trench 5, was brought into operation in 1960, and trenches 6 and 7 in 1961 and 1962, respectively. Trench 6 was operated for only a short period in 1961 because of breakthrough of ${ }^{90} \mathrm{Sr}$ and ${ }^{13^{7}} \mathrm{Cs}$ (i.e., small amounts of ${ }^{90} \mathrm{Sr}$ and ${ }^{137} \mathrm{Cs}$ were observed in a seep below the trench which indicated rapid movement from the trenchh to the surface seep; this transport was attributed to groundwater flow through fractures in the Conasauga shale). In 1962 pits 2, 3, and 4 and trench 5 were taken out of routine service; however, pit 4 is still used for disposal of sludge of low activity level from the Process Waste Water Treatment Plant (Lomenick, Jacobs, and Struxness, 1967). Trench 7 was taken out of service in 1965 as part of a plan to implement disposal of intermediate-level liquid waste by the process of hydrofracture in 1966. During the operation of the seepage pits and trenches, approximately 35 million gallons of waste, containing over 1 million curies of mixed fission products, were disposed of in this manner. Approximately half of this amount was ${ }^{90} \mathrm{Sr}$ and ${ }^{137} \mathrm{Cs}$, with most of the remainder being ${ }^{106} \mathrm{Ru}$. The waste contained considerably lesser amounts of ${ }^{125} \mathrm{Sb},{ }^{60} \mathrm{Co}$, and other mixed fission products (Lomenick, Jacobs, and Struxness, 1967).

In 1973 during reconnaissance sampling conducted for the burial ground studies at ORNL, the water in the seep associated with trench 7 was observed to contain higher amounts of ${ }^{6}{ }^{\circ} \mathrm{Co}$ than were present in waters near other pits and trenches. E. A. Bondietti, ORNL, suggested that the ${ }^{60} \mathrm{Co}$ was being transported as an organic complex and proposed that the organic may be EDTA (ethylenediaminetetraacetic acid). During the summer of $1974 \mathrm{~J}$. L. Means conducted studies on the ${ }^{60} \mathrm{Co}$-organic complex at ORNL. These studies subsequently led to a contract with Princeton University where much of the research described in this report was conducted.

This study has been limited to the hydrogeology of the trench 7 area. Of particular interest is the ground-water transport direction of ${ }^{60} \mathrm{Co}$ migration from trench 7 to the associated seep. This topic is discussed from the viewpoint of ${ }^{60} \mathrm{Co}$ concentrations in well waters and soils. Also, the ground-water concentrations of various nonradioactive chemicar species such as $\mathrm{Na}^{+}, \mathrm{NO}_{3}{ }^{-}$, and $\mathrm{SO}_{4}{ }^{2-}$ are considered. 
ORNL DWG 74-9604

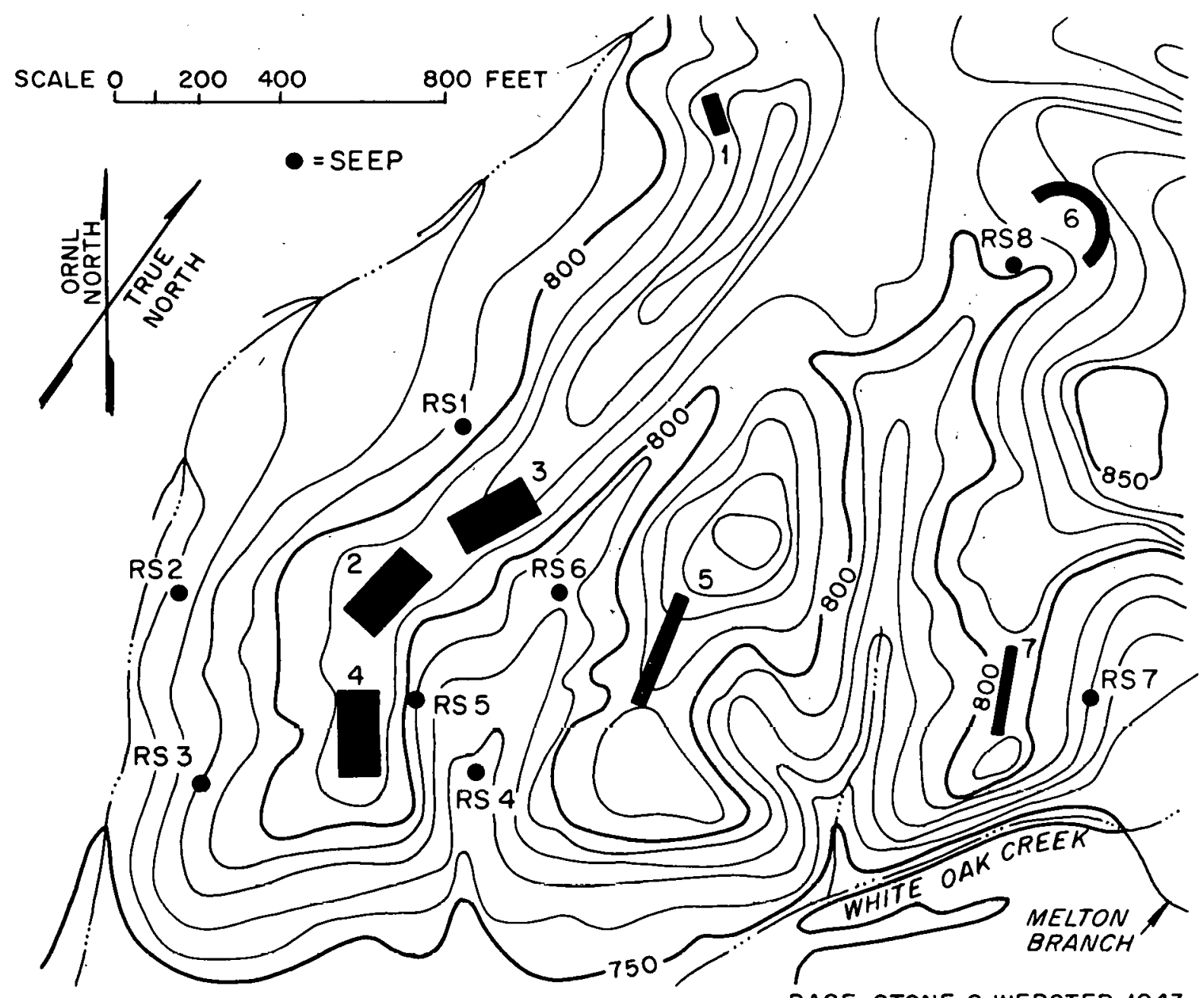

BASE: STONE \& WEBSTER, 1943

Fig. 1. Location of small seeps associated with seepage pits $1,2,3$, and 4 and trenches 5,6 , and 7 . 
The primary objective of the Princeton study has been to contribute to the understanding of ${ }^{60} \mathrm{Co}$ transport mechanisms and sediment-water interactions in the trench 7 area. Of the organic and inorganic species responsible for ${ }^{60} \mathrm{Co}$ mobilization, preliminary results now indicate that organic complexes predominate. Also, because the organic complexing characteristics of transition metals and transuranics are similar, the mechanisms of ${ }^{6}{ }^{\circ} \mathrm{Co}$ transport determined in this study may also apply to ${ }^{23}{ }^{3} \mathrm{Pu}$ which has been found in the soll of the seep. Also, the experimental and analytical methods. employed in this study will apply to the identification of other radionuclide complexes migrating from other trenches and pits and from the ORNL burial grounds.

\section{GROUND-WATER QUALITY NEAR TRENCH 7}

The ground-water quality in the vicinity of trench 7 is affected by the waste contained in the trench as well as two near-surface sources of contamination. These additional sources were formed by leakage from the intermediate-level liquid waste transfer line. One leak occurred during the operation of trench 7; it contaminated a small area approximately 150 $\mathrm{ft}$ north of the north end of the trench. The second contaminated area lies about $400 \mathrm{ft}$ northeast of seep RS-7 (Fig. 2). This second area was contaminated in 1972 by leakage from the transfer line between $X-10$ and the hydrofracture sity (Duguid and Sealand, 1975).

\section{Radionuclide Content}

A compilation of radionuclide analyses for waters collected between June 1974 and June 1975 from wells and the cobalt seep is given in Table 1. The primary constituents in the water are ${ }^{60} \mathrm{CO}$ and ${ }^{3} \mathrm{H}$, with some wells, T7-13 in particular, containing small quantities of ${ }^{125} \mathrm{Sb}$. Radioisotopes such as ${ }^{90} \mathrm{Sr},{ }^{137} \mathrm{Cs},{ }^{106} \mathrm{Ru}$, and the transuranics that have been detected in trace amounts in waters el sewhere in the White Oak Creek drainage basin are totally absent here. The location of wells in the trench 7 area is given in Fig. 2 .

One objective of this study has been to determine radionuclide migration routes from trench 7 to the cobalt seep (RS 7). Figure 3 is a map of well locations in the trench 7 area showing approximate dissolved ${ }^{60} \mathrm{Co}$ concentrations in $\mathrm{dpm} / \mathrm{ml}$ (1974 data) in the water. As shown in Table 1, the radionuclide contents of 1975 well waters parallel those of the 1974 samples, though absolute radionuclide concentrations in 1975 are, in general, lower. In defining the path of radionuclide transport from the trench to the seep, the following observations from Fig. 3 are of interest:

(1) The relatively high ${ }^{60} \mathrm{Co}$ concentrations in water from wells close to the trench, i.e., we11s T7-4, T7-5, and T7-8.

(2) The low ${ }^{60} \mathrm{Co}$ concentration in water from we11 T7-10 despite its 


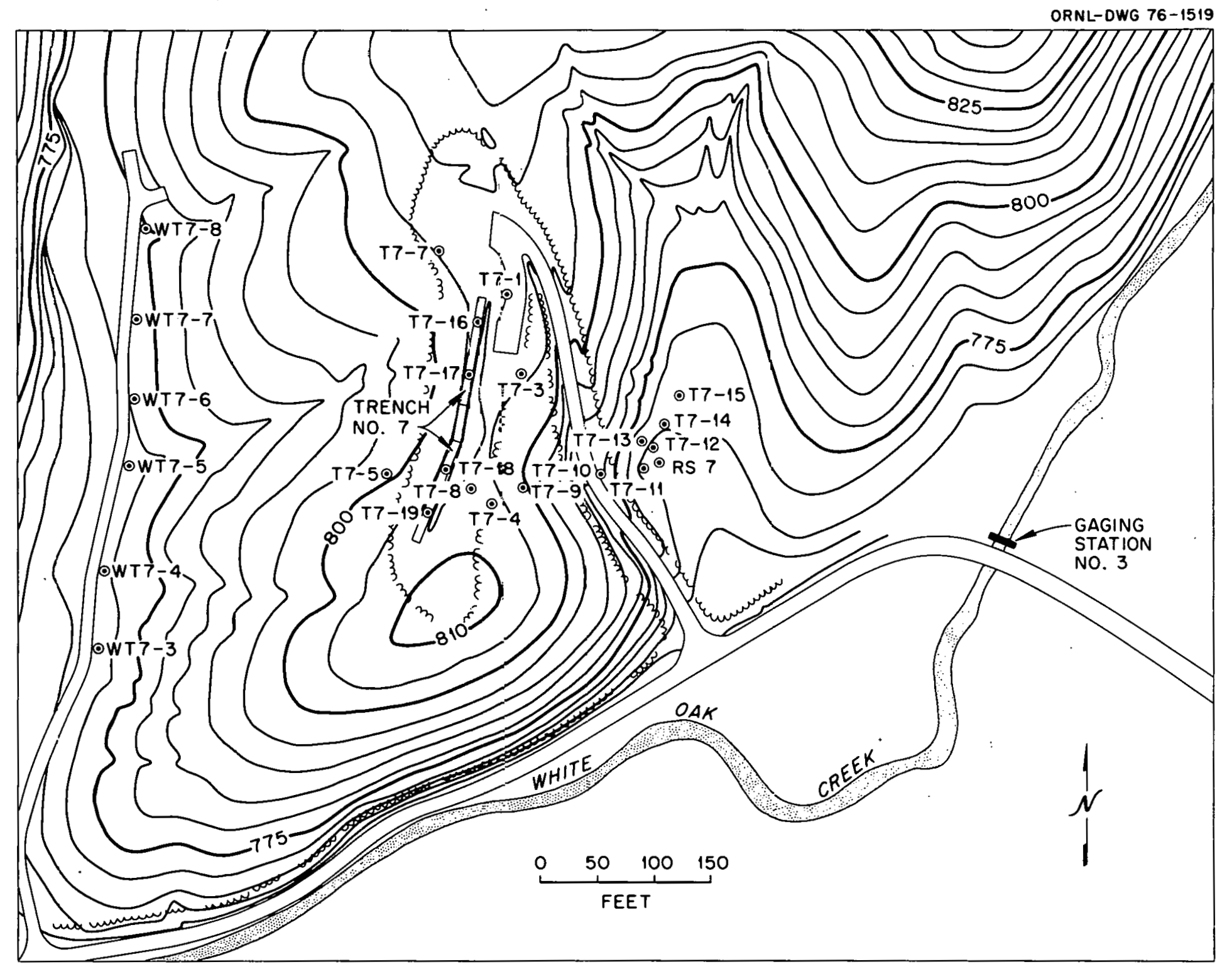

Fig. 2. Location of wells near trench 7. 
Table 1. Radionuclide analyses of water samples from wells in trench $7(\mathrm{dpm} / \mathrm{ml})$

\begin{tabular}{|c|c|c|c|c|}
\hline Well Code & Date & ${ }^{60} \mathrm{CO}$ & ${ }^{125} \mathrm{Sb}$ & $3_{H}$ \\
\hline \multirow[t]{3}{*}{$T 7-1$} & $7-12-74$ & 9.06 & $\ldots$ & --- \\
\hline & $7-22-74$ & 1.00 & 0.15 & $6.81 \times 10^{2}$ \\
\hline & $8-15-74$ & 11.5 & & -- \\
\hline \multirow[t]{4}{*}{$T 7-3$} & $7-12-74$ & $5.38 \times 10^{2}$ & -- & $2.91 \times 10^{3}$ \\
\hline & $7-22-74$ & $6.00 \times 10^{2}$ & --- & $3.90 \times 10^{3}$ \\
\hline & $8-15-74$ & $6.76 \times 10^{2}$ & -- & $2.34 \times 10^{3}$ \\
\hline & $6-20-75$ & $4.09 \times 10^{2}$ & 6.07 & $5.74 \times 10^{3}$ \\
\hline \multirow[t]{3}{*}{$T 7-4$} & $7-23-74$ & $1.12 \times 10^{3}$ & -- & $3.94 \times 10^{3}$ \\
\hline & $8-15-74$ & $9.64 \times 10^{2}$ & -- & $2.98 \times 10^{3}$ \\
\hline & $6-20-75$ & $1.02 \times 10^{3}$ & --- & $7.47 \times 10^{3}$ \\
\hline \multirow[t]{3}{*}{$T 7-5$} & $7-23-74$ & $1.04 \times 10^{3}$ & --- & $4.65 \times 10^{3}$ \\
\hline & $8-15-74$ & $9.36 \times 10^{2}$ & -- & $2.98 \times 10^{3}$ \\
\hline & $6-23-75$ & $3.53 \times 10^{2}$ & --- & $6.99 \times 10^{3}$ \\
\hline$T 7-8$ & $7-12-74$ & $9.81 \times 10^{2}$ & 44.2 & $9.85 \times 10^{2}$ \\
\hline \multirow[t]{6}{*}{$T 7-9$} & $6-26-74$ & $5.79 \times 10^{2}$ & --- & $6.30 \times 10^{2}$ \\
\hline & $7-1-74$ & $6.67 \times 10^{2}$ & -- & $4.58 \times 10^{2}$ \\
\hline & $7-11-74$ & $6.55 \times 10^{2}$ & --- & $7.28 \times 10^{2}$ \\
\hline & $7-22-74$ & $6.71 \times 10^{2}$ & -- & $7.19 \times 10^{2}$ \\
\hline & $8-15-74$ & $7.5 .1 \times 10^{2}$ & -- & $6.75 \times 10^{2}$ \\
\hline & $6-20-75$ & $5.53 \times 10^{2}$ & --- & $2.28 \times 10^{3}$ \\
\hline \multirow[t]{6}{*}{$T 7-10$} & $6-26-74$ & 13.4 & $-x=$ & $6.32 \times 10^{2}$ \\
\hline & $7-1-74$ & 10.1 & --- & -- \\
\hline & $7-12-74$ & 11.1 & - & $4.16, \times 10^{2}$ \\
\hline & $7-22-74$ & 14.5 & & -- \\
\hline & $8-15-74$ & 17.5 & $\ldots$ & $1.17 \times 10^{3}$ \\
\hline & $6-23-75$ & $2.18 \times 10^{2}$ & -- & $7.2 \times 10^{2}$ \\
\hline
\end{tabular}


Table 1..(contd)

\begin{tabular}{|c|c|c|c|c|}
\hline Well Code & Date & ${ }^{60} \mathrm{Co}$ & ${ }^{125} \mathrm{Sb}$ & $3_{H}$ \\
\hline \multirow[t]{3}{*}{$T 7-11$} & $7-31-74$ & $5.18 \times 10^{2}$ & $\cdots$ & $3.93 \times 10^{3}$ \\
\hline & $8-15-74$ & $7.12 \times 10^{2}$ & $-\cdots$ & $4.11 \times 10^{3}$ \\
\hline & $6-23-75$ & $3.33 \times 10^{2}$ & -- & $1.26 \times 10^{3}$ \\
\hline \multirow[t]{2}{*}{$T 7-12$} & $7-31-74$ & $5.47 \times 10^{2}$ &.- & $3.45 \times 10^{3}$ \\
\hline & $8-15-74$ & $7.61 \times 10^{2}$ & --- & $4.16 \times 10^{3}$ \\
\hline \multirow[t]{3}{*}{$T 7-13$} & $8-6-74$ & $8.16 \times 10^{2}$ & 28.6 & $3.74 \times 10^{3}$ \\
\hline & $8-15 / 74$ & $6.39 \times 10^{2}$ & 23.1 & $4.11 \times 10^{3}$ \\
\hline & $6-23-75$ & $6.07 \times 10^{2}$ & $18: 3$ & $2.86 \times 10^{3}$ \\
\hline \multirow[t]{3}{*}{$T 7-14$} & $7-31-74$ & $2.27 \times 10^{2}$ & -- & $1.90 \times 10^{3}$ \\
\hline & $8-15-74$ & $3.61 \times 10^{2}$ & -- & $2.25 \times 10^{3}$ \\
\hline & $6-23-75$ & 93.7 & $-\cdots$ & $7.2 \times 10^{2}$ \\
\hline \multirow[t]{3}{*}{$T 7-15$} & $7-37-74$ & $.1 .53 \times 10^{2}$ & $\cdots$ & $2.09 \times 10^{3}$ \\
\hline & $8-15-74$ & $1.81 \times 10^{2}$ & --- & $2.36 \times 10^{3}$ \\
\hline & $6-23-75$ & 6.11 & -- & -- \\
\hline \multirow[t]{4}{*}{$R S=7$} & $6-26-74$ & $6.69 \times 10^{2}$ & -- & $3.05 \times 10^{3}$ \\
\hline & $7-12-74$ & $5.15 \times 10^{2}$ & --- & $3.25 \times 10^{3}$ \\
\hline & $7-23-74$ & $4.63 \times 10^{2}$ & --- & $3.28 \times 10^{3}$ \\
\hline & $8-15-74$ & $5.35 \times 10^{2}$ & --- & $3.07 \times 10^{3}$ \\
\hline - & $6-23-75$ & $4.22 \times 10^{2}$ & $-\cdots$ & $6.23 \times 10^{2}$ \\
\hline WT7-3 & $6-25-75$ & 16.9 & -- & $4.61 \times 10^{3}$ \\
\hline \multirow[t]{2}{*}{ WT7-4 } & $8-15-74$ & 42.1 & -- & $5.30 \times 10^{3}$ \\
\hline & $6-25-75$ & 14.5 & -- & $3.54 \times 10^{3}$ \\
\hline \multirow[t]{2}{*}{ WT7-5 } & $8-15-74$ & 19.6 & -- & $1.72 \times 10^{3}$ \\
\hline & $6-25-75$ & 0.98 & 0.151 & --- \\
\hline \multirow[t]{2}{*}{ WT7-6 } & $8-15-74$ & 0.322 & -- & --- \\
\hline & $6-25-75$ & 3.51 & --- & --- \\
\hline
\end{tabular}


Table 1 (contd)

\begin{tabular}{ccccc}
\hline We11 Code & Date & ${ }^{60}{ }_{\text {Co }}$ & ${ }^{125_{S b}}$ & ${ }^{3} \mathrm{H}$ \\
\hline WT7-7 & $6-25-75$ & 0.527 &.-- &.-- \\
WT7-8 & $8-15-74$ & $1.52 \times 10^{2}$ & --- & $5.52 \times 10^{2}$ \\
& $6-25-75$ & 0.164 & 0.111 &.-- \\
\hline
\end{tabular}

--- = below detection limits. 

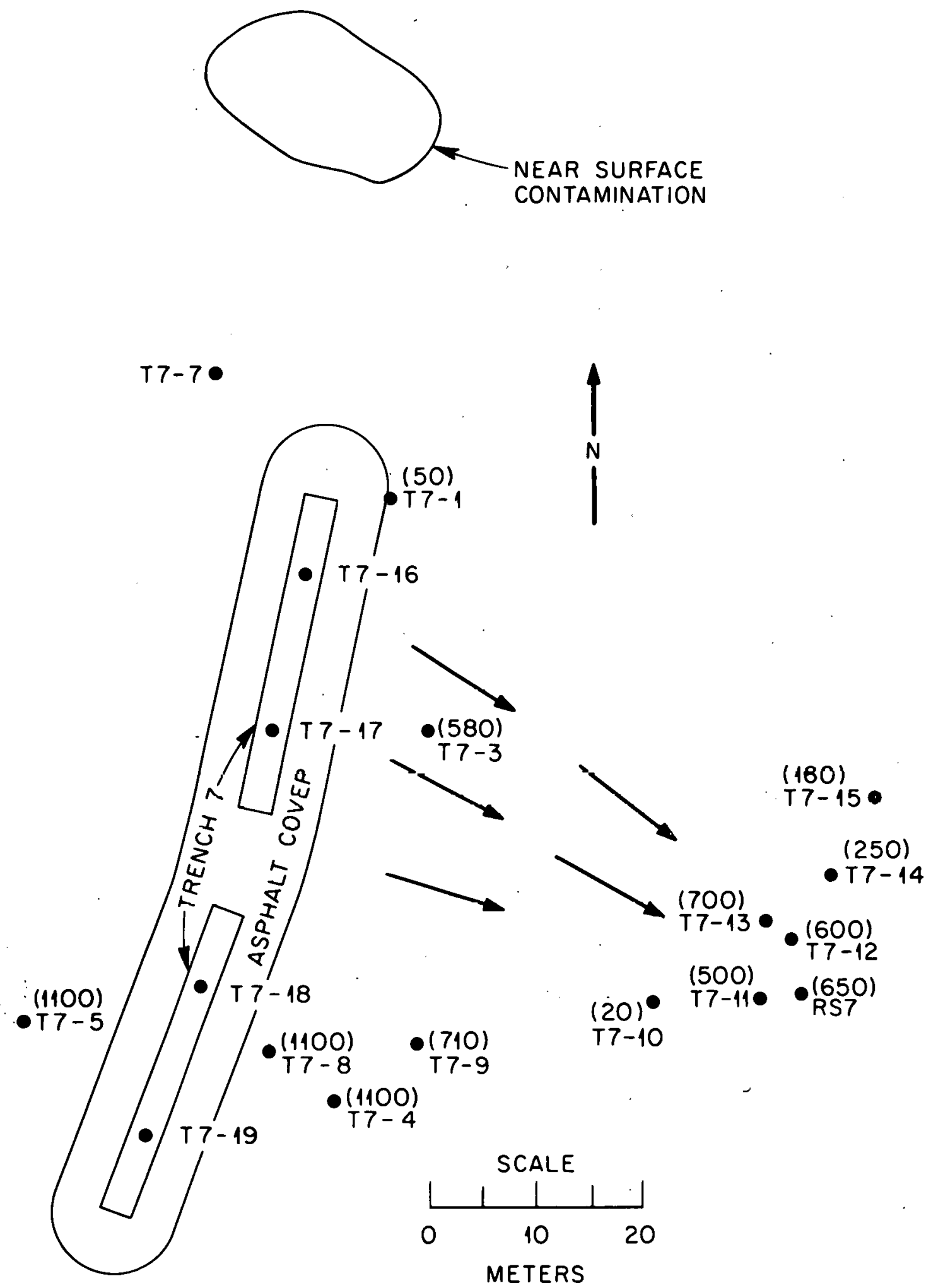

Fig. 3. Location of wells and the cobalt seep, the approximate ${ }^{60} \mathrm{Co}_{0}$ concentration in $\mathrm{dpm} / \mathrm{ml}$ (1974 data), and the probable direction of groundwater flow. 
proximity to both the seep and well $\mathrm{T} 7-9$, which has a higher ${ }^{60} \mathrm{Co}$ concentration.

(3) The "fanning" distribution of ${ }^{60} \mathrm{Co}$ in we11s T7-11, T7-12, T7-14, and $T 7-15$--that is, the greatest activity is in T7-12, and ${ }^{6}{ }^{\circ}$ Co concentrations decrease to the northeast toward T7-15 and to the southwest toward T7-11.

The data imply radionuclide migration from the trench to the seep as illustrated by arrows in Fig. 3. This idea is confirmed by the ${ }^{3} \mathrm{H}$ concentrations in these well water samples which closely parallel the ${ }^{60} \mathrm{Co}$ contents (Fig. 4).

This interpretation of the direction of radionuclide transport disagrees with the hypothesis (Lomenick, Jacobs, and Struxness, 1967) that groundwater in the Conasauga shale moves parallel to the strike of bedrock, which in this case is delineated by the line of wells T7-8, T7-9, T7-10, and seep RS7. It also implies that the ILW line leak north of the trench is dispersing negligible activity to the cobalt seep.

The idea that radionuclide migration is along strike is refuted by the relatively low radionuclide concentrations measured in water from we11 T7-10. Both ${ }^{60} \mathrm{Co}$ and ${ }^{3} \mathrm{H}$ appear to be moving in the ground water in the area of wells T7-8, T7-4, and T7-9, but do not reach well T7-10 in significant quantities.

The contaminated area north of the trench does not appear to be currently providing ${ }^{60} \mathrm{Co}$ to the seep for the following reasons:

(1) If the ${ }^{60} \mathrm{Co}$ is moving from the ILW line leak in ground water that flows down the topographical depression leading to the seep (Fig. 2), higher concentrations of ${ }^{60} \mathrm{Co}$ should be measured in we11s T7-14 and T7-15.

(2) Or if the radionuclide is first moving south from the ILW line leak area toward the trench and subsequently being directed east toward the seep, higher concentration should be present in the water of well T7-1.

A second zone of contaminated soil resulting from another ILW leak to the northeast of the seep, termed ILW leak No. 2 (Duguid, 1975a) is an additional potential source for the ${ }^{60} \mathrm{Co}$ in the seep. Analys is of the surface radiation field of this area with a survey meter demonstrated that an apron of relatively lower level gama activity extends from the original leak along a topographical depression toward the seep. But the contamination appears to decrease substantially before reaching the seep. More detailed analyses of ground water and soll cores are needed to evaluate the role of this leakage area in radionuclide migration.

Two limitations to this analysis of radionuclide migration routes are that radioactive waste received by the trench was not chemically homogeneous and that radionuclides may be retained by sediments. Consequently, 

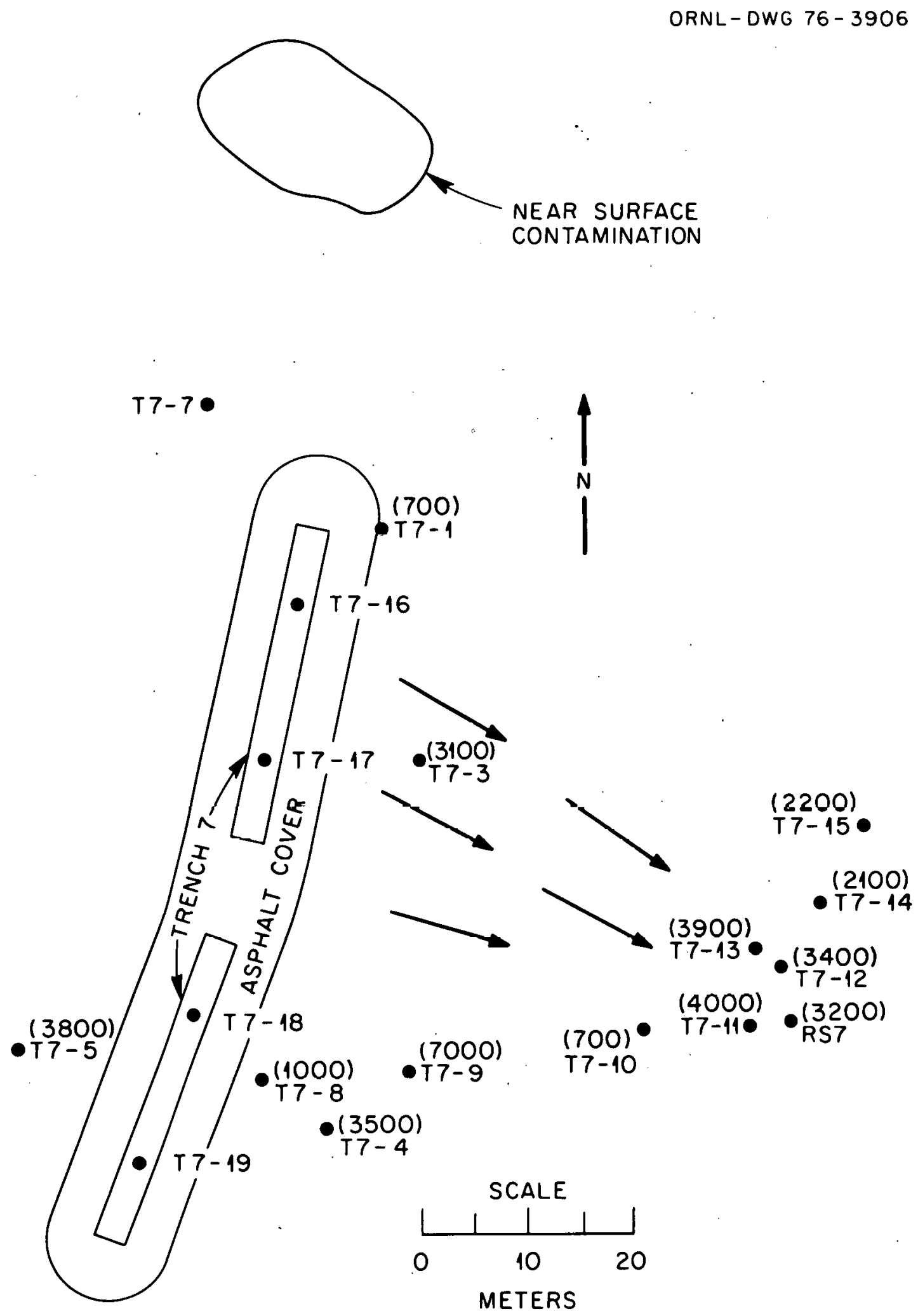

Fig. 4. Location of wells and the cobalt seep, the approximate concentration of $3 \mathrm{H}$, in $\mathrm{dpm} / \mathrm{ml}$ (1974 data), and the probable direction of ground-water flow. 
the ground water may contain disproportionate amounts of ${ }^{3} \mathrm{H}$ and ${ }^{60} \mathrm{Co}$ owing to heterogeneities of original radioactive wastes; or the ground water receiving flow from the trench may possess 1 ittle ${ }^{60} \mathrm{Co}$ because of sediment uptake. Despite these uncertainties, the high ${ }^{60} \mathrm{Co}$ concentrations of selected water samples collected between trench 7 and the seep suggest that radionuclide migration is occurring as shown in Fig. 3.

The data in Table 1 indicate that radionuclide migration is also occurring from trench 7 to the west, based on the presence of ${ }^{60} \mathrm{Co}$ and ${ }^{3} \mathrm{H}$ in wel1s T7-5, WT7-8, WT7-6, WT7-5, and WT7-4 (Fig. 2). This leakage decreased in 1975, however. Water from we11 T7-5 contains only about onethird of its $1974{ }^{60} \mathrm{Co}$ concentration, though its ${ }^{3} \mathrm{H}$ content has increased. And wells WT7-3 through WT7-8 possess only a fraction of their previous ${ }^{60} \mathrm{Co}$ and ${ }^{33} \mathrm{H}$ components.

High radioisotope concentrations in we 11 T7-4 suggest radionuclide migration from the trench toward the southeast, where a steep downhill topographical gradient occurs. This is difficult to confirm because of the lack of wells in this area. But radioisotope migration from the south end of the trench is anticipated since this section received the bulk of radioactive wastes dumped into the trench ( $\mathrm{J}$. 0 . Duguid, personal communication).

In general, radionuclide transport from trench 7 was less in June 1975 than during the summer of 1974. Waters from only three of nineteen wells $(T 7-12, T 7-4, T 7-10)$ showed increases in ${ }^{60} \mathrm{Co}$ contents. The 1975 ${ }^{6} \mathrm{Co}$ concentrations were down by an average of one-third. For ${ }^{60} \mathrm{Co}$, which has a half-life of 5.2 years, this is a much greater decrease than can be accounted for by radioactive decay alone.

Tritium concentrations in the majority of well waters also decreased in 1975, some by a factor 5 . Tritium increases were evident in those wells containing ${ }^{6}{ }^{\circ} \mathrm{Co}$ increases in 1975: T7-12, T7-4, and T7-10, and also in T7-3 and 77-5, which showed a ${ }^{60}{ }^{\circ}$ Co decrease. Possible explanations for the overall decrease in radionuclide transport are (1) less water percolating through the trench to mobilize the radionuclides, or (2) a decrease in the amount of water-soluble radionuclides in the trench due to fixation in the shale, or (3) in the case of ${ }^{60} \mathrm{Co}$, a decrease in the amount of complexing agent available.

\section{Nonradioactive Constituents}

Intermediate-level liquid waste solutions were treated chemically prior to delivery to the pits and trenches to create a high pH environment in which generally most radionuclides have low aqueous solubility, therefore reducing subsequent radionuclide mobility. An analysis of the intermediate level waste in 1962 yielded the following chemical composition (1962 Intra-laboratory correspondence from E. G. Struxness to 0 . M. Sealand): 


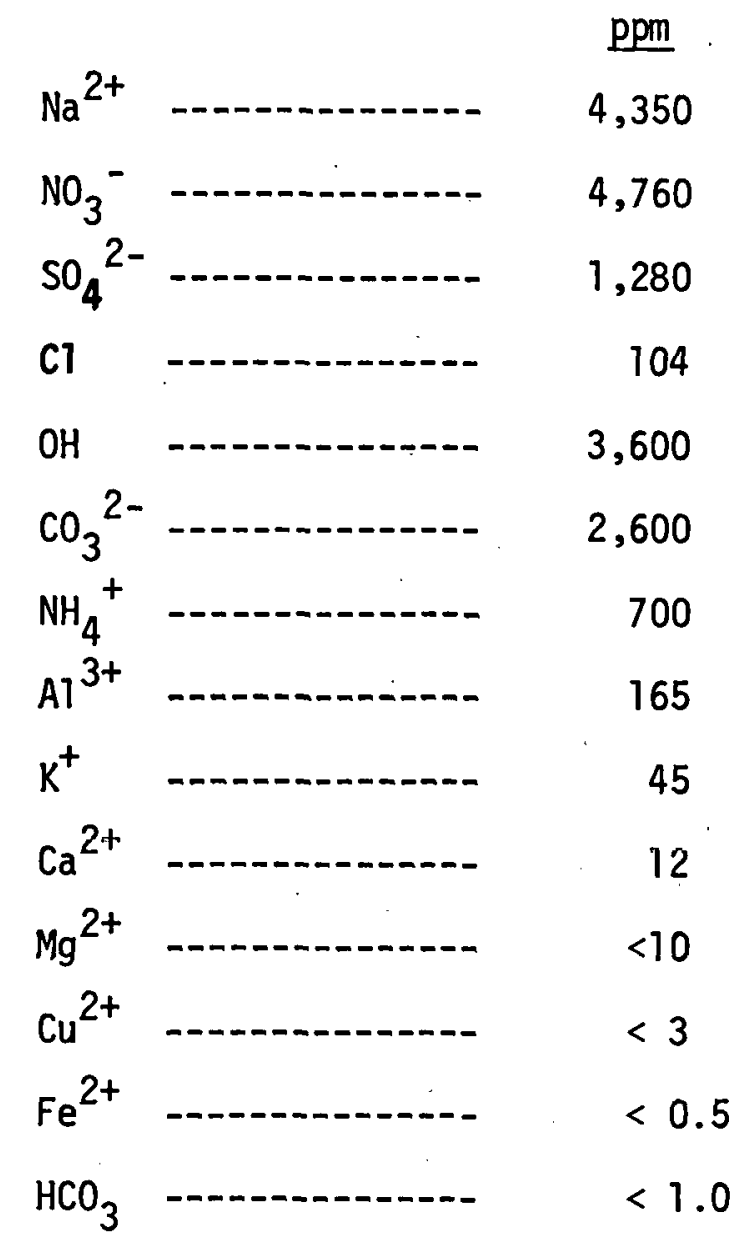

Cobalt-60 bearing waste migrating from trench 7 to the seep would be expected to be high in $\mathrm{NO}_{3}^{-}$, $\mathrm{SO}_{4}{ }^{2-}$, and $\mathrm{Cl}^{-}$in that these components are not strongly sorbed by the Conasauga shale and their distributions are not $\mathrm{Ph}$ dependent under environmental conditions. Even though original waste waters are high in $\mathrm{Na}^{2+}, \mathrm{NH}_{4}{ }^{+}$, and other cations, their concentrations would be reduced via sorption by clays, etc. The $\mathrm{OH}^{-}$and $\mathrm{CO}_{3}{ }^{2-}$ concentrations are controlled by the $\mathrm{pH}$ buffering capacity of the shale.

Figure 5 illustrates the positive correlation between ${ }^{60} \mathrm{Co}$ concentrations and $\mathrm{Na}^{+}, \mathrm{NO}_{3}{ }^{-}$, and $\mathrm{SO}_{4}{ }^{2-}$ in well and seep waters collected August 15,1974 . The high $\mathrm{Na}^{+}$concentrations are significant because they imply that cation sorption sites in the shale in contact with ${ }^{60} \mathrm{Co}$-bearing ground waters are saturated. A rough positive correlation between ${ }^{60} \mathrm{Co}$ and $\mathrm{Cl}^{-}$was also detected. In similar comparisons of ${ }^{60} \mathrm{Co}$ with $\mathrm{Ca}^{2+}, \mathrm{K}^{+}$, and $\mathrm{Mg}^{2+}$ concentrations, no such relationships were observed. Results similar to those in Figure 5 are illustrated in Figure 6 , which is based on well and seep samples collected in June, 1975.

Similarities in molar ratios of anion concentrations in well water provide evidence consistent with the above suggestion that flow from the 


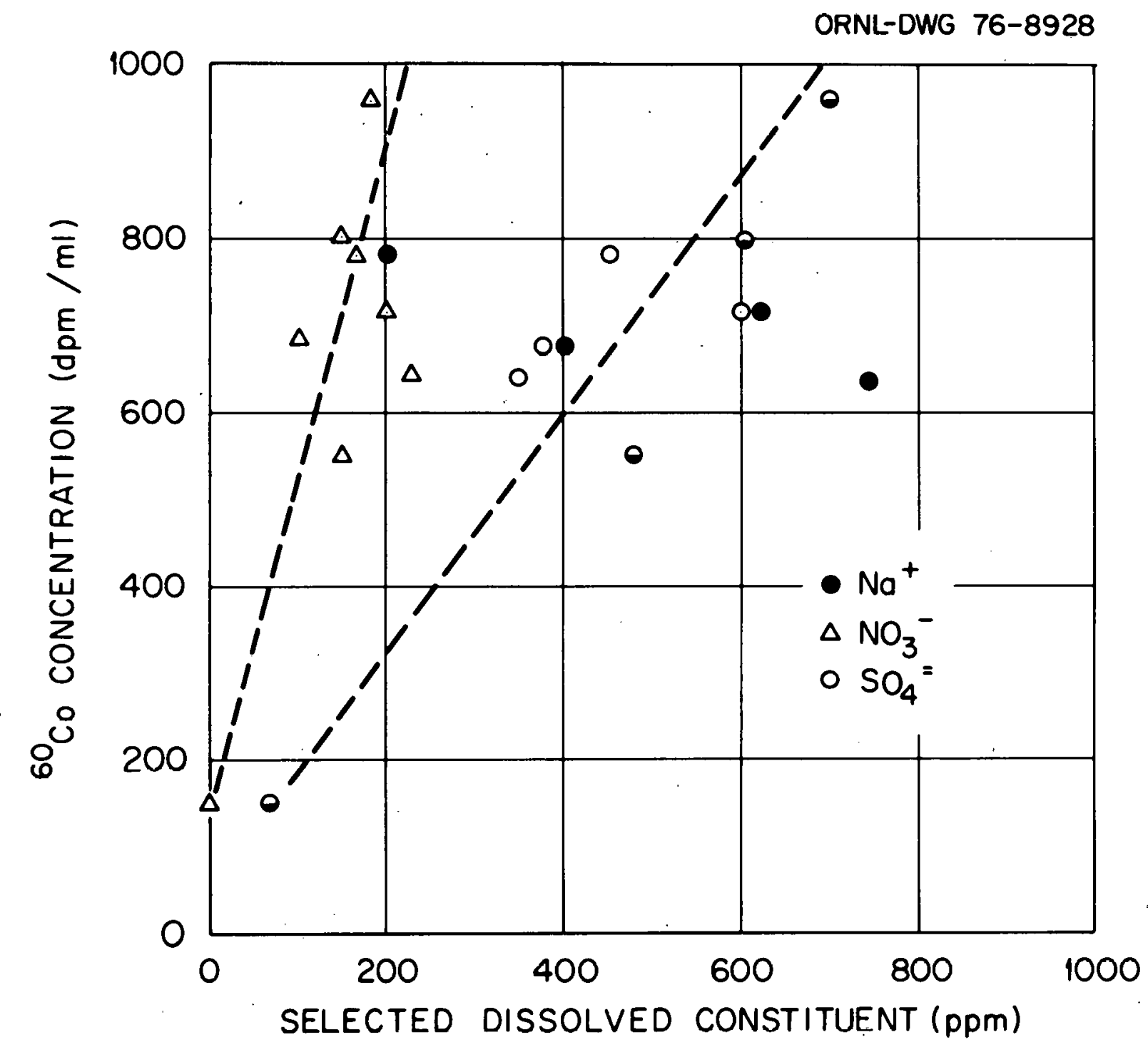

Fig. 5. Concentration of $\mathrm{NA}^{+}, \mathrm{NO}_{3}^{-}$, and $\mathrm{SO}_{4}{ }^{2-}$ versus ${ }^{60} \mathrm{Co}$ in well and seep water near trench 7 (August 1974). 


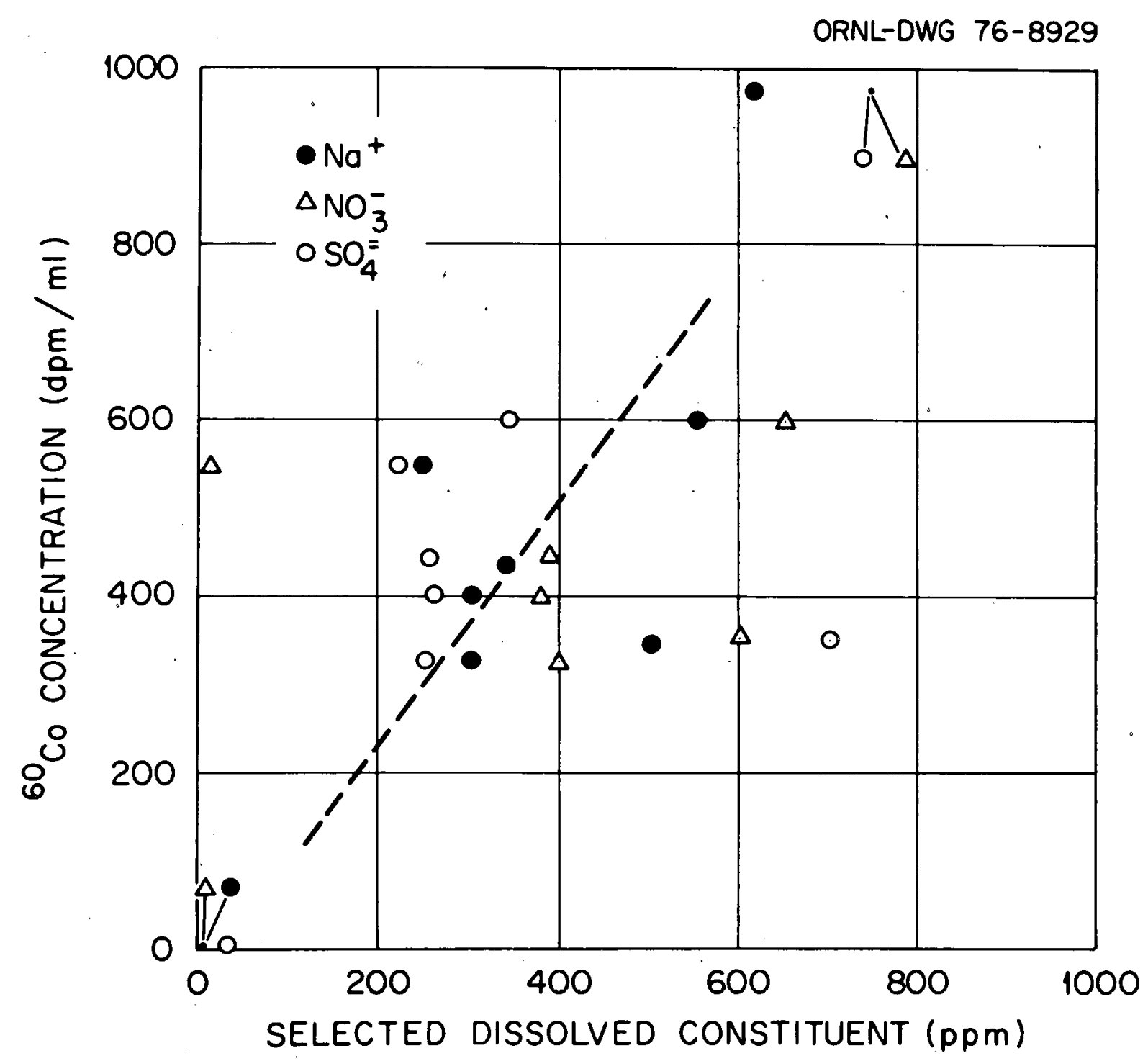

Fig. 6. Concentration of $\mathrm{Na}^{+}, \mathrm{NO}_{3}{ }^{-}$, and $\mathrm{SO}_{4}{ }^{2-}$ versus ${ }^{60} \mathrm{Co}$ in well and seep water near trench 7 (June 1975). 
trench to the seep occurs predominantly along a line roughly parallel to wells T7-3, T7-13, and T7-12. Note that during the summer of 1974, $\mathrm{NO}_{3}-/ \mathrm{SO}_{4}{ }^{2-}, \mathrm{Cl}^{-} / \mathrm{SO}_{4}{ }^{2-}$, and $\mathrm{Cl} / \mathrm{NO}_{3}{ }^{-}$were nearly equal in water from these wells, but for example, were generally quite different from those of well T7-9.

Well \# Collection Date

$\mathrm{MNO}_{3}-\mathrm{MSO}_{4}{ }^{2-}$

$\mathrm{MCl}^{-}, \mathrm{MSO}_{4}{ }^{2-}$

$\mathrm{M}^{-} 1^{-} / \mathrm{MNO}_{3}^{-}$

\begin{tabular}{lllll}
\hline T7-3 & $7 / 22 / 74$ & 0.45 & .07 & 0.15 \\
T7-13 & $8 / 6 / 74$ & 0.55 & .16 & 0.29 \\
T7-12 & $7 / 12 / 74$ & 0.49 & .18 & 0.37 \\
T7-12 & $8 / 15 / 74$ & 0.44 & .16 & 0.36 \\
T7-3 & $8 / 15 / 74$ & 0.43 & .07 & 0.16 \\
T7-9 & $8 / 15 / 74$ & 0.017 & .0025 & 0.15
\end{tabular}

The same relationship holds for samples taken from these wells during June, 1975.

Well \# Collection Date

$\mathrm{MNO}_{3}-\mathrm{M}_{\mathrm{SO}}{ }_{4}^{2-} \quad \mathrm{M}_{\mathrm{Cl}}{ }^{-}, \mathrm{M}_{\mathrm{SO}_{4}}{ }^{2-}$

$\mathrm{M}^{-}{ }^{-}, \mathrm{M} \mathrm{NO}_{3}^{-}$

\begin{tabular}{lllll}
\hline T7-3 & $6 / 20 / 75$ & 2.14 & 0.129 & 0.060 \\
T7-13 & $6 / 25 / 75$ & 3.23 & 0.168 & 0.052 \\
T7-12 & $6 / 23 / 75$ & 2.57 & 0.177 & 0.069 \\
T7-9 & $6 / 20 / 75$ & 4.00 & 0.093 & 0.023
\end{tabular}

Comparisons of these anion ratios with those in intermediate level waste involved in ILW leak \#2 northeast of the seep in order to evaluate the possible role of this leakage zone in supplying the seep with ${ }^{60} \mathrm{Co}$ is not possible because of the lack of anion ratio data in the original waste solution.

Field Measurements of $\mathrm{pH}$, Eh, and Temperature

Field measurements, such as $\mathrm{pH}$, temperature, and Eh (using a platinum electrode), were made on unfiltered water samples (June 1975) immediately after collection. Then water samples were filtered through ashless Whatman filter paper, and total alkalinity was measured by ti.tration to pH 4.5 with 0.1 N HCi.

Although no correlation exists between ${ }^{60} \mathrm{Co}$ concentration and the $\mathrm{pH}$ of these samples, there is a distinct correlation between the $\mathrm{pH}$ and 
the proximity to the trench (Table 2). The pH of samples collected near (as close as 10-15 ft) the trench is generally low, whereas that of samples from the seep area is generally much higher.

This is unusual in that waste solutions deposited in the trench were of high pH. Consequentiy a pattern of higher $\mathrm{pH}$ solutions near the trench trending into lower $\mathrm{pH}$ solutions at greater distance would be expected. However, because of the high $\mathrm{HCO}_{3}{ }^{-}$and $\mathrm{CO}_{3}{ }^{2-}$ content of intermediate level waste solutions, alkalinity may be a better indicator for the presence of trench derived solutions. Note that alkalinity is highest along the proposed direction of flow from the trench to the seep parallel to wells $77-3, T 7-13, T 7-11$, and RS-7.

Field-measured ground-water temperatures ranged from $21^{\circ} \mathrm{C}$ at RS-7 where water is collected only several inches below the surface of the ground to $15.5-16^{\circ} \mathrm{C}$ in wells where the depth to the water table is greater than $15 \mathrm{ft}$ (Table 2). The latter temperature probably approximates the mean annual grount-water temperature of the region.

\section{COBALT-60 TRANSPORT MECHANISMS}

\section{Cation Exchange Resin Data}

An interesting aspect of ${ }^{6}{ }^{\circ} \mathrm{Co}$ in the ground water of the trench 7 area is that it does not readily exchange with cation-exchange resins (Rexyn $101-\mathrm{Na}^{+}$- form). Data from several samples show that only about $5-35 \%$ of the ${ }^{60} \mathrm{Co}$ is lost to the exchange column, $65-95 \%$ therefore being retained as a tightly bonded complex in solution.

Cobalt-60 was added to standard solutions of inorganic and organic ligands to determine the bond strengths of resulting complexes. Sulfate, nitrate, bicarbonate, chloride, and orthophosphate solutions exchanged virtually $100 \%$ of the ${ }^{60} \mathrm{Co}$ to the column. However, polyphosphates such as pyrophosphate $\left(\mathrm{Na}_{4} \mathrm{P}_{2} \mathrm{O}_{7} 1 \mathrm{H}_{2} \mathrm{O}\right)$ and tetrametaphosphate $\left(\mathrm{NaPO}_{3}\right)_{6}$, which could conceivably be present in trench 7 from detergents used in cleanup operations, showed strong complexing. The ${ }^{60} \mathrm{Co}$ was retained by pyrosphosphate at concentrations of $10^{-1} \mathrm{M}$, but not at $10^{-4} \mathrm{M}$, which is still far in excess of the total phosphate concentration in ground-water samples from the area. Tetrametaphosphate retained about $65 \%$ of the ${ }^{60} \mathrm{Co}$ at $10^{-4} \mathrm{M}$, but complete exchange occurred at $10^{-6} \mathrm{M}$, which is the average total phosphate concentration in the ground water. This is taken as strong evidence that phosphate complexation of ${ }^{60} \mathrm{Co}$ is not the principal mechanism of radionuclide transport from trench 7 . However, these analyses do suggest that polyphosphates in greater concentration could form strong bonds with ${ }^{60} \mathrm{Co}$ and increase its mobility in the environment. Their presence should be avoided where retention of ${ }^{60} \mathrm{Co}$ is desired.

Thus the chelation of ${ }^{60} \mathrm{Co}$ is almost certainly occurring with the stronger organic ligands. In 1973, E. A. Bondietti of ORNL suggested that 
Table 2. Field $\mathrm{pH}$, temperature, total alkalinity, and dissolved $\mathrm{Ca}^{2+}$ of water samples collected near trench 7 (June 1975)*

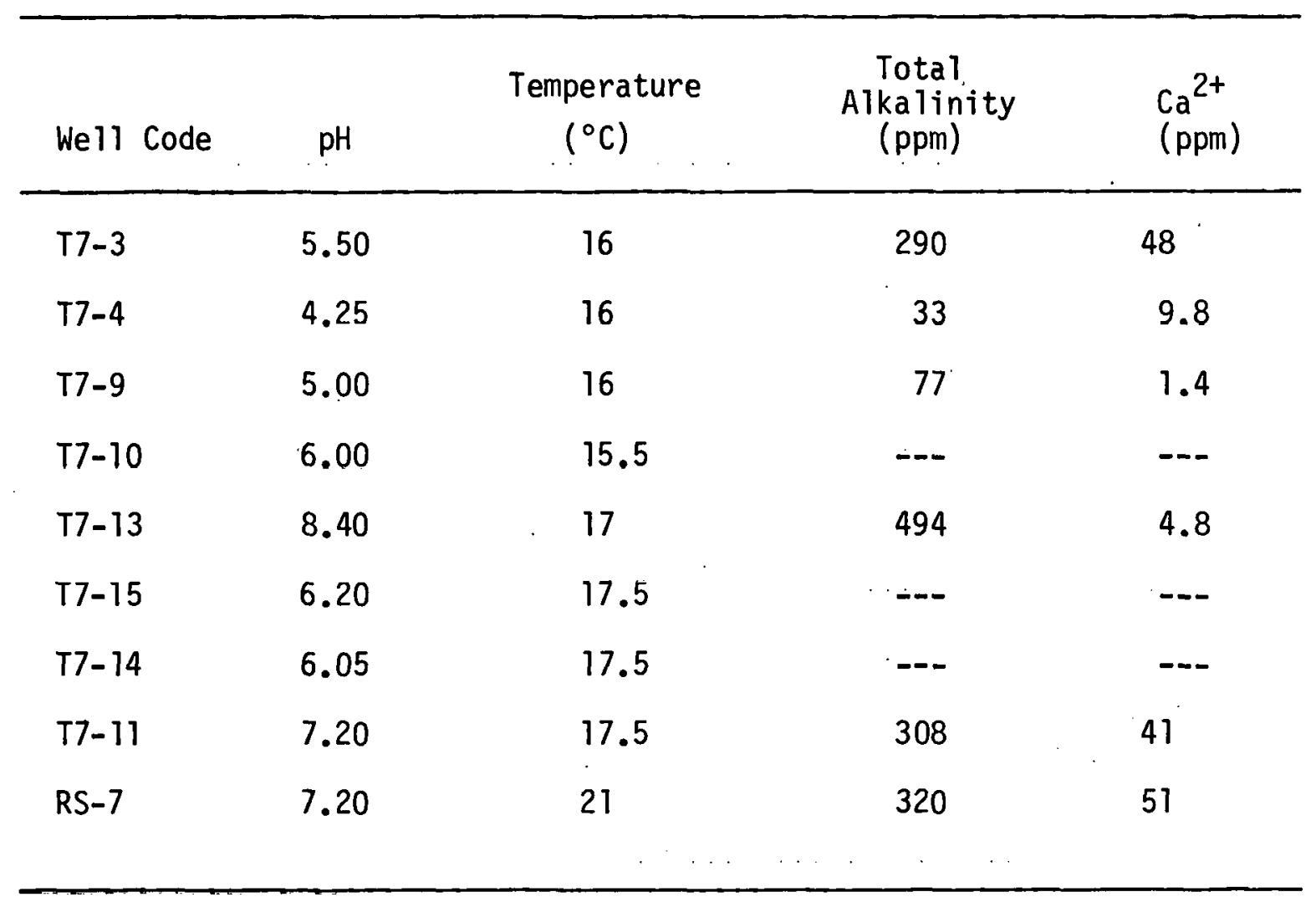

*Samples are listed in approximate order of increasing distance from the trench. 
${ }^{60} \mathrm{Co}$ is transported as a complex with EDTA. EDTA is used in cleanup and decontamination operations at ORNL, and hence it is found in liquid waste. But no proof that EDTA is actually present in the system has yet been provided.

Our cation-exchange data indicate that $10^{-6} \mathrm{M}$ EDTA solutions spiked with ${ }^{60} \mathrm{Co}$ retain $90 \%$ or more of the ${ }^{60} \mathrm{Co}$ after passing through $\mathrm{Na}^{+-}$ exchange resins (Rexyn 101). The reaction of $\mathrm{Co}^{2+}$ with EDTA has a stabi1ity constant of $10^{16.31}$ (Sillen and Martel1, 1971). Therefore if EDTA is present in the system, it is surely forming strong complexes with the ${ }^{6}{ }^{\circ} \mathrm{Co}$. Methods for the detection of EDTA will be discussed in a later section of this paper.

Potentiometric Titration Results

Contaminated ground water from the trench 7 area was eluted through cation-exchange resins (Rexyn, $\mathrm{H}^{+}$-form) for removal of cationic constituents. These solutions were subsequently treated for $\mathrm{CO}_{2}$ removal and then potentiometrically titrated with dilute $\mathrm{NaOH}$ in an attempt to detect an organic complexing agent through its chemical buffering characteristics. Resulting titration curves revealed irregular buffering patterns. Numerous buffers, including silicates, phosphate, sulfates, etc., present in large quanitites in addition to the organic chelates, which are presumably present as traces, were probably responsible for the irregular results obtained. If these competing inorganic constituents could be removed and the organic chelates concentrated, detection of the organics through potentiometric titrations might be possible.

A feasible method for detecting trace quantity organic buffers by this method is as follows. Contaminated well water is first eluted through $\mathrm{H}^{+}$-form exchange resins for removal of cationic constituents. This low pH solution is then freeze-dried, during which process volatile inorganic constituents such as $\mathrm{HCl}$ and $\mathrm{H}_{2} \mathrm{SO}_{4}$ are subl imated. An almost pure organic residue will remain (Rashid and King, 1969). This residue is then dissolved in distilled $\mathrm{H}_{2} \mathrm{O}$, which is treated for $\mathrm{CO}_{2}$ removal and potentiometrically titrated with dilute base. Through this treatment nonvolatile organic chelates present in original ground water as traces are concentrated 100-fold, and competing inorganic buffering agents are removed. Therefore if a chelate is present as a dominant constituent of the organic residue, potentiometric titration may reveal its identity and approximate concentration.

Natural Organic Acids as Trace Metal Complexers: Background

In addition to the possibility of complexation with synthetic organic chelates such as EDTA, ${ }^{6}$ Co may al so be complexed with natural organic acids such as humic and fulvic acids. Kee (1961) has cited the inability of cation-exchange resins to adsorb metals when bonded with natural organic acids. Therefore results of $\mathrm{Na}^{+}$-exchange resin experiments 
described above may be attributed to complexation of ${ }^{60} \mathrm{Co}$ with natural organic acids as well as synthetlc chelating compounds.

Natural organic acids are well-known heavy metal chelators. Malcolm et al. 1968) report conditional stability constants of $10^{2} .7,10^{4} .0$, and $10^{6} .6$ for $\mathrm{Co}^{2+}$--fulvic acid complexes at $\mathrm{pH} 3.0,4.5$, and 6.0 , respectively; Schnitzer and Skinner (1967) have measured 10,.7 at $\mathrm{pH} 5.0$. Furthermore, Leland (1973) states that of all transition metals, Co ${ }^{2+}$ some of the strongest complexes with humic and fulvic acids.

Dissolved organic material has been detected at 2-35 ppm in all well waters from the trench 7 area, especially those from the seep where the water is yellow with organic color. The source of this material is probably primarily the soll and to a lesser extent, the Conasauga shale. Studies are now in progress to chemically differentiate organic materials from these two sources, particularly on the basis of molecular weight and functional group contents. In that different organics vary in their ability to complex trace metals, chemical characterization of the organics vary in their ability to complex trace metals, chemical characterization of the organics is vital to understanding their possible role in radionuclide transport.

Molecular Weight of Organics from Dialysis

In attempting to determine whether ${ }^{60} \mathrm{Co}$ is complexing with large molecular weight organic acids, samples from four different wells were dialyzed. Cellulose dialysis membranes containing 10-ml samples of contaminated well water were placed in beakers with $90 \mathrm{ml}$ distilled deionized water and stirred for $24 \mathrm{hr}$. Dialysis membranes will allow passage of compounds with molecular weights up to about 7,000 to 10,000 . Therefore large molecular weight organics will be retained within the membrane, along with any ${ }^{60} \mathrm{Co}$ bonded to the organics.

After the 24-hr reaction period, the ${ }^{60} \mathrm{Co}$ originally present within the dialysis membranes had diffused so that about as much ${ }^{6}{ }^{\circ} \mathrm{Co}$ was detected outside the membrane as within, therefore, suggesting that the organic ${ }^{60} \mathrm{Co}$ complexes in the ground water have molecular weights of less than $7,000-10,000$.

Molecular Weight of Organics from Gel Chromatography

The organic complexes in ground water can be separated according to molecular weight using Sephadex chromatographic gels. The use of Sephadex gels for chromatographic separation of organic molecules is a tool used extensively by biochemists, and it has recently applied to systems containing natural organic acids (Ghassemi, 1968; Kemp and Wong, 1974; Flaig, 1971; Rashid and King, 1969; Rashid, 1971).

Following an adapted procedure from Rashid and King (1969), Sephadex gel G-10 was soaked for about 3 days in an excess quantity of buffer 
solution consisting of $0.1 \mathrm{~N} \mathrm{NaCl}$. Columns of $50 \times 2.0 \mathrm{~cm}$ dimensions were used, and the height of the gels in the packed column was uniformly maintained at $35 \mathrm{~cm}$. Contaminated well water was concentrated by freeze drying and reextracted with $10 \mathrm{ml}$ distilled water. $\mathrm{Na}^{+}$-exchange resin characteristics of solutions before and after this step revealed that original organic-metallic structures were preserved during this procedure. A sample of $1 \mathrm{ml}$ of the extracted concentrated well water solution was introduced on the surface of the gel, and elution was continued with the $0.1 \mathrm{~N} \mathrm{NaCl}$ buffer at a constant flow rate of $25 \mathrm{ml} / \mathrm{hr}$. The unabsorbed fraction of the sample was collected in 3- to 5-ml fractions, which were analyzed for ${ }^{60} \mathrm{Co}$ and monitored for natural organics (phenyl groups) at $450 \mathrm{~mm}$ on a DU spectrophotometer. Natural organic and ${ }^{60} \mathrm{Co}$ concentrations throughout the elution profile are illustrated in Fig. 7.

Sephadex gel G-10 is designed to retard the passage of organic solutes with molecular weights less than 700 . Everything greater than 700 MW is eluted first. Lighter molecules are eluted later and fractionated so that the lightest compounds are the last to emerge from the column. Inorganic solutes, being the smallest, are strongly retarded by the gels. Therefore, any ${ }^{6}$ Co appearing in the organic fractions is chemically associated with the organics. Two peaks representing organic acid concentrations are apparent in both samples shown in Fig. 8. The greater than 700-MW peak constitutes the principal organic fraction in the sample from the seep, and the less than 700-MW fraction predominates in the sample from well T7-3. These data show that $82-88 \%$ of the ${ }^{60} \mathrm{Co}$ is complexed with a compound of molecular weight less than 700 . About 12-18\% of the ${ }^{60} \mathrm{Co}$ is associated with the greater than 700-MW fraction. This, however, may represent an overlap of the lighter molecular weight organics, which peak in concentration several milliliters later in the elution profiles.

The bulk of the ${ }^{60} \mathrm{Co}$ is transpurted by the less than $700 \mathrm{MW}$ fraction, which implies complexation with low molecular weight natural or synthetic organics. Chelation with EDTA (MW $=292$ ) cannot be dismissed but the results of these experiments do not relate to possible EDTA transport of ${ }^{6} \mathrm{Co}$ since EDTA does not absorb at $450 \mathrm{~mm}$.

To specify what kind of organic acids may be involved in ${ }^{60} \mathrm{Co}$ complexation, ${ }^{\circ} \mathrm{Co}$ will be added, to standard solutions of EDTA, fulvic acid, gallic acid, etc., and eluted through Sephadex gel G-10. Comparison of the elution behavior of ${ }^{6}{ }^{\circ} \mathrm{Co}$ complexed with these ligands with those of natural samples should indicate to what extent natural organic acids and/or synthetic organics such as EDTA are responsible for ${ }^{\circ}$ Co transport in the trench 7 area. Furthermore, natural organics from the trench samples separated into molecular weight fractions by this method may be chemically characterized by the techniques described in the previous section.

\section{Application of the Computer Program WATEQ}

The computer program WATEQ developed recently by Truesdell and Jones (1974) may also be useful in delineating the chemical equilibrium of 


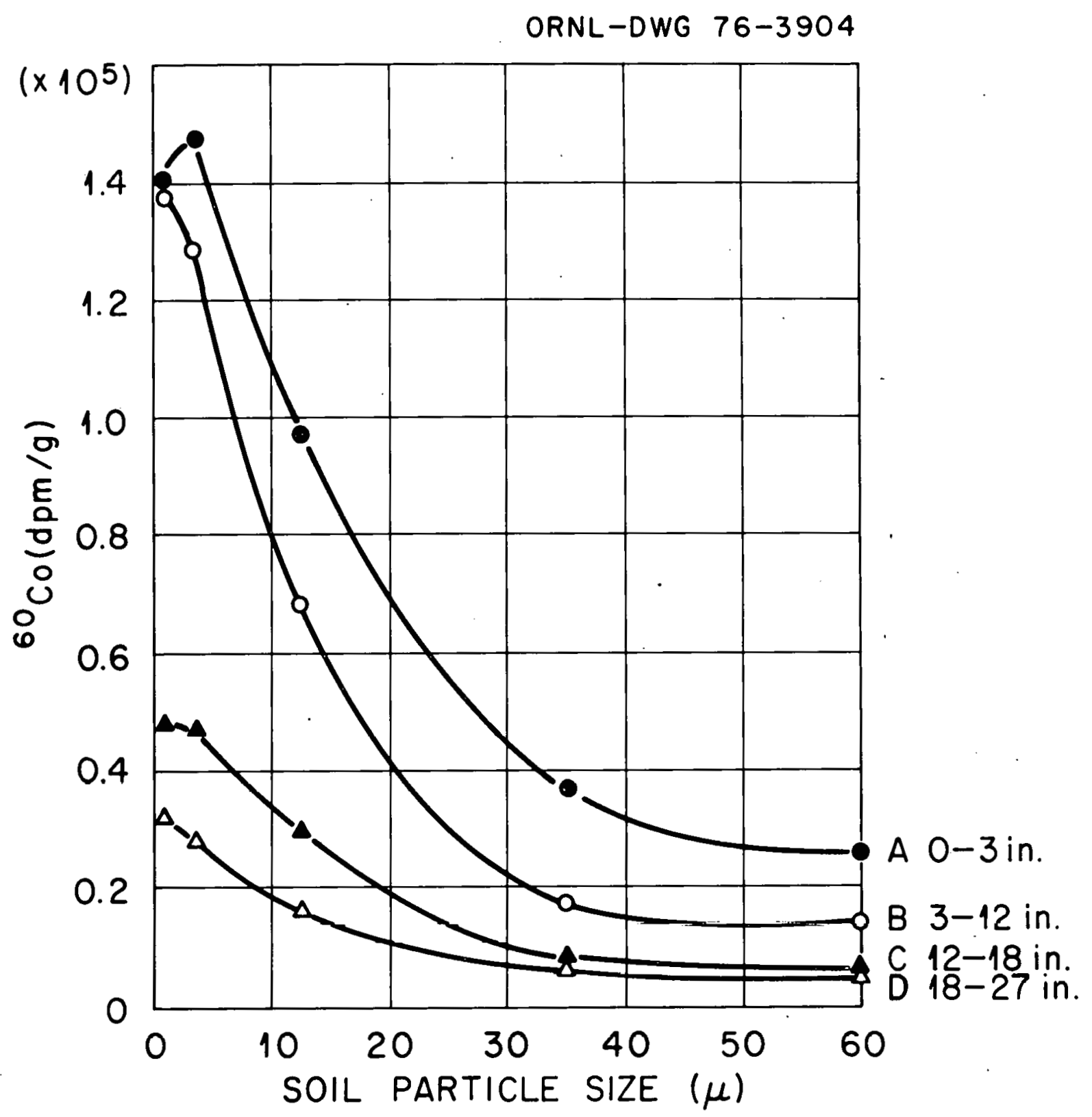

Fig. 7. Cobalt-60 concentration in relation to particle size in four samples from the soil profile near the cobalt secp. 


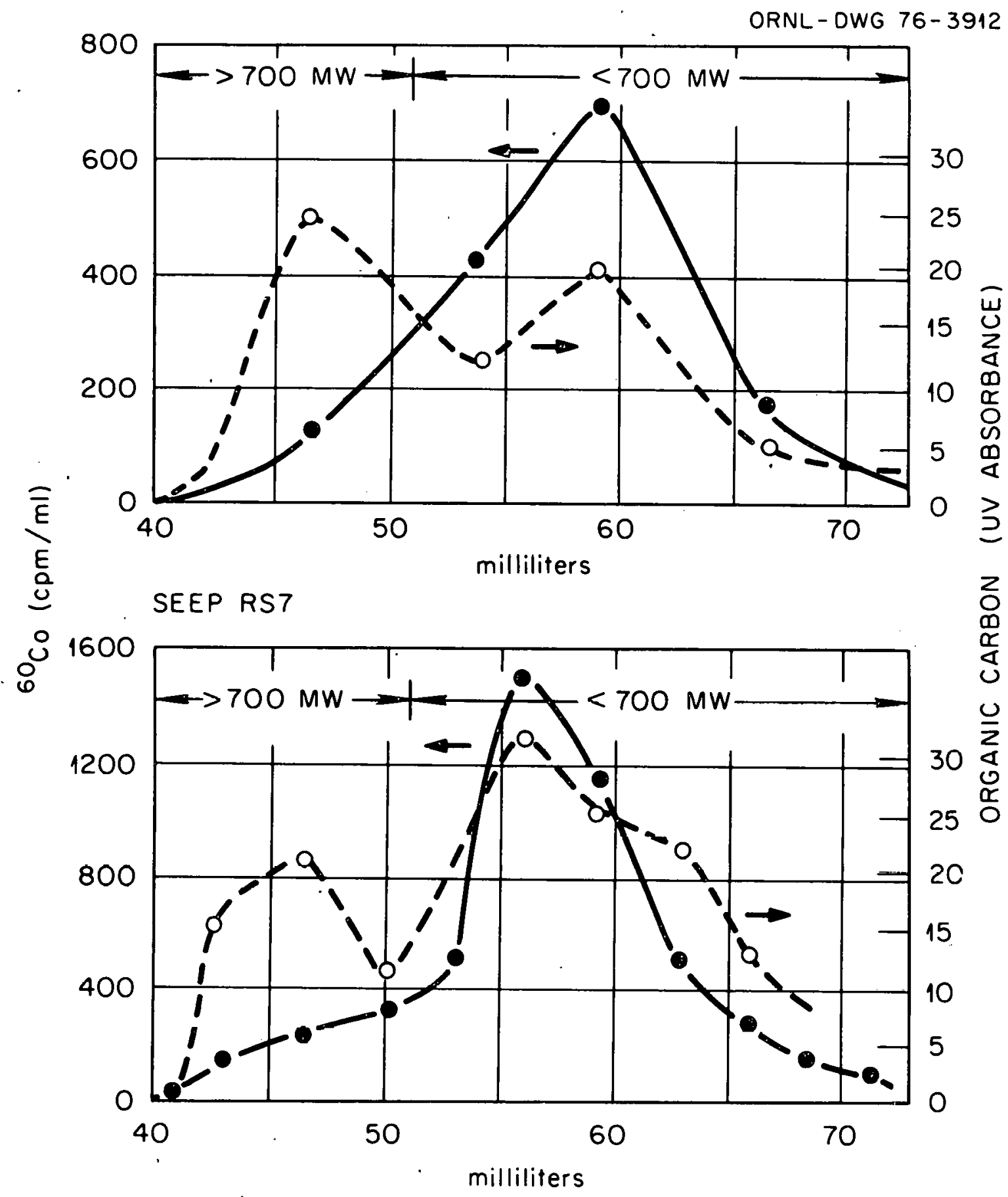

WELL T $7-3$

Fig. 8. Elution profiles of water samples from well T7-3 and the cobalt seep. 
ground water in this study. Given the temperature, $\mathrm{pH}$, redox potential, and analytic concentrations of seventeen or more elements, WATEQ calculates the equilibrium activities and concentrations of eighty-five aqueous species and the saturation state of a similar number of common minerals or amorphous solids. Data such as EH, pH, organic carbon, and concentrations of principal dissolved cations and anions were collected from numerous well water samples from the trench 7 area. It is believed that WATEQ may be capable of giving some meaning to this mass of data in terms of the chemical equilibrium of the principal complexes present and the complexes that radionuclides would be most likely to form.

For the present study, WATEQ will be revised to include cobalt equilibria and all inorganic and organic complexes of potential significance tn mobilizing the metal within ground-water systems. These revisions will also include organic ligands such as carboxylic, humic, and fulvic acids and EDTA. In this way, organic effects on cobalt mobilization can be quantified.

As an example, WATEQ has been applied to analytical data for seep RS-7. Here $\mathrm{pH}$ and Eh were measured at 7.95 and 0.210 volts, respectively. The results show that the ground water is saturated in the following minerals: biotite, calcite, dolomite, amorphous $\mathrm{Fe}$ and $\mathrm{Al}$ oxyhydroxides, illite, kaolinite, and sericite. In contrast, water from well T7-4, which is just east of the trench, at a more acid $\mathrm{pH}$ of 5.3 is saturated only in kaolinite. It is interesting to note that biotite, calcite, $\mathrm{Fe}$ and $\mathrm{Al}$ sesquioxides, and 711 ite are all strong ${ }^{90} \mathrm{Sr}$ and ${ }^{137} \mathrm{Cs}$ sorbents (Tamura, 1963, 1965). Calcite, in particular, effectively coprecipitates Sr (Varga and Jacobs, 1970; Lomenick et a1., 1967; Holland et al., 1964). Water $\mathrm{pH}$ may therefore exert strong controls on soil mineralogy, simple radionuclide complexes, and free ions.

\section{COBALT-60 ADSORPTION MECHANISMS}

Upon identification of the ${ }^{60} \mathrm{Co}$ complexes in migration from the trench 7 area, meaningful distribution coefficient and adsorption kinetics experiments can be conducted. Whether ${ }^{60} \mathrm{Co}$ is adsorbed as an uncomplexed ion or as an entire complex or whether it is adsorbed from the complex by the soil is not known. However, the spiked seep water-shale adsorption experiment discussed below suggests that the uncomplexed ion is the specie which is sorbed.

Wallace and Lunt (1956) reported that entire Fe EDTA complexes become fixed to clays by the reaction:

$$
\begin{gathered}
X-\text { EDTA - Fe }+0-\text { clay } \ddagger X-\text { EDTA - FeO - clay } \\
\text { where } X=(\mathrm{Na}, \mathrm{K}, H \text {, etc. })
\end{gathered}
$$


They report that adsorption of nonionic Fe-EDTA complexes was greater than that of anionic species. However, there is some question as to whether these experimental results were actually indicating adsorption of entire complexes or whether the sol1 was selectively adsorbing $\mathrm{Fe}^{3+}$ from the EDTA. Norvell and Lindsay (1969) also reported adsorption of FeEDTA in soils, but indicated that adsorption of the metal onto soil from EDTA complexes was greater than adsorption of the entire FeEDTA complex. Little information on adsorption of trace metals as natural organic complexes by soils is available in the literature. However, adsorption of polar organic molecules by clays is a widely known phenomenon (Grim, 1968).

\section{Spiked Seep Water--Shale Adsorption Experiment}

Preliminary studies suggest that chelated ${ }^{60} \mathrm{Co}$ resists adsorption by sediments, which allows the radionuclide to be transported from the trench to the seep and into White Oak Creek. The unchelated ${ }^{60} \mathrm{Co}$ is strongly fixed by the Conasauga shale. The following experiment illustrates this point.

Seep water containing about $240 \mathrm{cpm} / \mathrm{ml}$ chelated ${ }^{60} \mathrm{Co}$ (determined by the $\mathrm{Na}^{+}$-exchange resin method) was spiked with ${ }^{8}{ }^{\circ} \mathrm{CoCl}_{2}$, bringing its total activity to about $1100 \mathrm{cpm} / \mathrm{ml}$. Chelated ${ }^{6}{ }^{\circ} \mathrm{Co}$ in this solution (again determined by the $\mathrm{Na}^{+}$-exchange resin method) was slightly greater than that of the original solution, about $260 \mathrm{cmp} / \mathrm{ml}$. The increase indicates that a small proportion of the ${ }^{60} \mathrm{Co}$ spike added was complexed by organic chelate(s) present in the water. Therefore about one-fourth of the ${ }^{60} \mathrm{Co}$ in the final solution was strongly complexed, and approximately three-fourths was in a weakly complexed or ionic form. Aliquots of this solution were then equilibrated with two 1-g Conasauga shale samples,

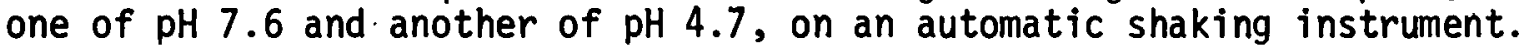
After 18 and $42 \mathrm{hr}$, soil suspensions were centrifuged and samples were taken from the supernatant 1 iquid and analyzed for ${ }^{60} \mathrm{Co}$. The concentrations in both samples after $42 \mathrm{hr}$ deviated little from those after $18 \mathrm{hr}$, indicating that equilibration between ${ }^{60} \mathrm{Co}$ in the s011 and water occurred before $18 \mathrm{hr}$. Also the $\mathrm{pH}$ of these final soil suspensions changed very little during the reaction. About $230 \mathrm{cpm} / \mathrm{ml}{ }^{6}{ }^{\circ} \mathrm{Co}$ remained in the seep water of $\mathrm{pH} 7.6$, which was about equal to the amount of chelated ${ }^{60} \mathrm{Co}$ in the spiked seep water. This suggests that inorganic or weakly complexed ${ }^{60} \mathrm{Co}$ was adsorbed, whereas the chelated ${ }^{60} \mathrm{Co}$ resisted fixation. In the $\mathrm{pH} 4.7$ sample somewhat more ${ }^{60} \mathrm{Co}$ was adsorbed; about $180 \mathrm{cpm} / \mathrm{m} 1{ }^{60} \mathrm{Co}$ remained in the supernatant 7 igand. Here, too, it appears that inorganic or weakly complexed ${ }^{60} \mathrm{Co}$ was preferentially adsorbed. Perhaps adsorption of a small amount of ${ }^{60} \mathrm{Co}$ as a ${ }^{60} \mathrm{Co}$-organic complex is indicated. However, it is more likely that some ${ }^{6}{ }^{\circ} \mathrm{Co}$ was displaced from strong complexes by $\mathrm{H}^{+}$in the low $\mathrm{pH}$ environment, thus making it available for adsorption as an ion or weakly bound complex. 


\section{Concentration of ${ }^{60} \mathrm{Co}$ Related to Soll Particle Size}

From the previous discussion it is evident that the Conasauga shale has a high adsorbtion capacity for ionic or weakly complexed ${ }^{60} \mathrm{Co}$. It is of interest to know what soil constituents, e.g., clays, amorphous metal oxides, are the strongest ${ }^{60} \mathrm{Co}$ sorbents.

Mn oxides and iron sesquioxides (Jenne, 1968; Jenne and Wahlberg, 1968; and Pickering, 1970) and possibly insoluble organic matter (Barsdate, 1968; Leland et al., 1973; and Sorathesn et al., 1960) are reported to be strong $\mathrm{Co}^{2+}$ adsorbers. Manganese oxides have a particularly high adsorption capacity for $\mathrm{Co}^{2+}$ (Jenne, 1968; Leland et a1., 1973, and Murray et a1., 1968; Murray, 1975a; 1975b). But iron oxyhydroxides are more abundant in the Conasauga shale.

Data have been collected on ${ }^{60} \mathrm{Co}$ content versus particle size distribution of soil from the trench 7 seep. If ${ }^{\circ}{ }^{\circ} \mathrm{Co}$ is adsorbed by clays, it should be restricted to the less than $2 \mu$ fractions. If iron and manganese oxide particle coatings are the adsorbing media, then ${ }^{60} \mathrm{Co}$ should be observed in all size fractions. However, ${ }^{6}$ Co would be enriched in the finer particle size because of the greater particle surface area.

Dried portions of soil samples from the cobalt seep were separated into the size fractions: greater than $50 \mu, 20-50 \mu, 5-20 \mu, 2-5 \mu$, and $0.2-2 \mu$, using a procedure described by Jackson (1956, page 123).

The data (Fig. 7), using the criteria discussed above point to adsorption of ${ }^{\circ} \mathrm{Co}$ by iron and/or manganese oxides rather than clays. This result is reenforced by the fact that clay concentrations are not greatest in the seep soil horizon containing the most ${ }^{6}{ }^{\circ} \mathrm{Co}$, which would be expected if ${ }^{6}{ }^{\circ} \mathrm{Co}$ was adsorbed by clays (Fig. 9). Clay concentration is greatest in sample $C$, where the ${ }^{60} \mathrm{Co}$ concentration is lower. On the other hand, extractable $\mathrm{MnO}_{2}$ (Chao, 1972, for method) is present in these samples in the order: $A>B>C>D$, which al so corresponds the their ${ }^{6}{ }^{\circ} \mathrm{Co}$ concentrations. An attempt to differentiate between the $\mathrm{MnO}_{2}$, amorphous Fe oxide, and insoluble organic components as ${ }^{60} \mathrm{Co}$ sorbents is discussed in the following section.

Adsorption of $\mathrm{MnO}_{2}$, Fe Sesquioxides, and Insoluble Organics

Research has been undertaken to isolate and identify ${ }^{60} \mathrm{Co}$-adsorbing substrates in the Conasauga shale by wet chemical extractions. The methods of Chao (1972) for acidified hydroxylamine hydrochloride dissolution of $\mathrm{MnO}_{2}$ and Schwertmann (1973) for selective extraction of amorphous Fe oxide by the oxalate method have been used. Half-gram sediment samples from eighteen different sites were selectively extracted for $\mathrm{MnO}_{2}$. The remaining soil fractions were then extracted for Fe sesquioxides. Extractants were analyzed for $\mathrm{Mn}$ and $\mathrm{Fe}$ by atomic absorption and for ${ }^{60} \mathrm{Co}$ by scintilation counting. The amount of ${ }^{\circ}{ }^{\circ} \mathrm{Co}$ associated with each phase was quantified for each sample using a two equation--two unknown system. 


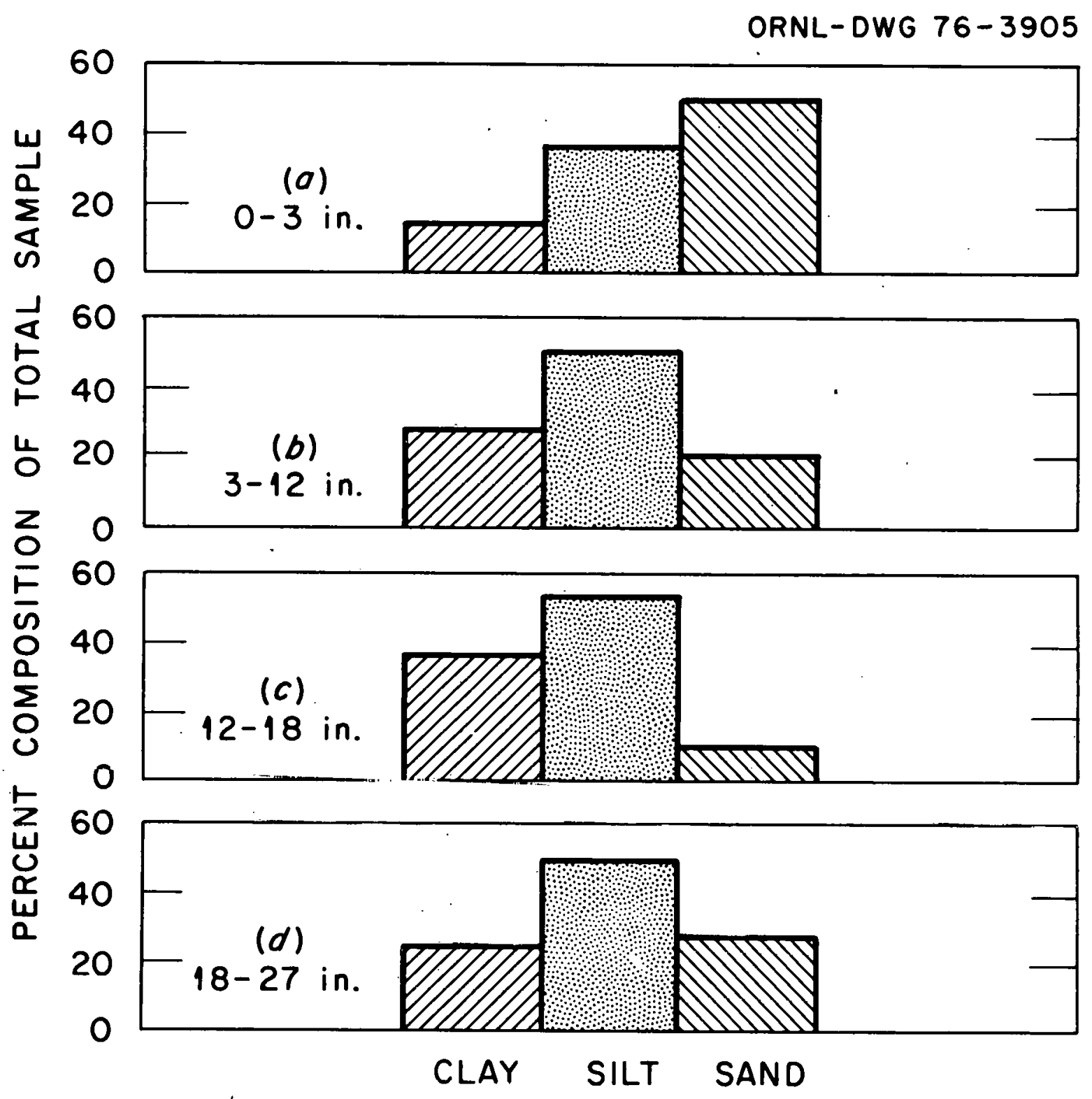

Fig. 9. Percent of clay, silt, and sand in four samples from the soil profile near the cobalt seep. 
Calculations to date suggest that $\mathrm{MnO}_{2}$ is the principal ${ }^{60} \mathrm{Co}$ sorbent, possessing $85-98 \%$ of the ${ }^{60} \mathrm{Co}, \mathrm{Fe}$ sesquioxides containing the other $2-15 \%$. Organic carbon contents of these samples will be determined, and statistical correlation coefficients for adsorption by $\mathrm{MnO}_{2}, \mathrm{Fe}$ sesquioxide, and organic carbon in the solls will be obtained. It is anticipated that the amount of ${ }^{60} \mathrm{Co}$ adsorbed onto insoluble organics is small.

\section{CONCLUSIONS}

The ${ }^{60} \mathrm{Co}$ transported in ground water near trench 7 occurs primarily as organic complexes, which reduce the sediment adsorption capacity for the radionuclide. Manganese oxides in the Conasauga shale appear to be the principal absorbents of ionic and weakly complexed ${ }^{60} \mathrm{Co}$.

Data collected from observation wells between the trench and a seep to the east of the trench indicate that ${ }^{60} \mathrm{Co}$ migration occurs from the trench to the seep. This opposes the idea that much of the ${ }^{60} \mathrm{Co}$ observed in the seep arises from a small near-surface area of contamination to the north of the trench formed by accidental leakage from waste transfer lines. The role of a similar area of contamination to the northeast of the seep in transporting ${ }^{60} \mathrm{Co}$ to the seep is not yet known.

The migration and adsorption mechanisms sought in the ORNL waste management studies are necessary before corrective measures can be taken to reduce radioactivity transport from buried waste. The leakage of ${ }^{60} \mathrm{Co}$ into the ground water around trench 7 affords an excellent opportunity for studies of properties of adsorption and transport of a transition metal trace element. The easy detectability of ${ }^{60} \mathrm{Co}$ makes its use highly advantageous in studies of this nature. And because the organic complexing characteristics of transition metals and transuranics are similar (Sillen and Martell, 1971), the mechanisms of ${ }^{60}$ Co transport determined in this study will also apply to plutonium and other alphaemitters, which have been detected in the soil of the trench 7 seep. 


\section{REFERENCES}

Barsdate, R. J., 1968, Transition metal binding by large molecules in high latitude waters, in proc. Symp. Org. Matter in Natural Waters, D.'W. Wood, ed., Inst. Marine Sct., Univ. of Alaska, 485 pp.

Beck, K. C. Reuter, J. H., and Perdue, E. M., 1974, Organic and inorganic geochemistry of some coastal plain rivers of the southeastern U. S., Geochim. Cosmochim. Acta 38, 347-364.

Chao, T. T., 1972, Selective dissolution of manganese oxides from soils and sediments with acidified hydroxylamine hydrochloride, SSSAP $\underline{36}$, 764-768.

Duguid, J. 0., and Sealand, 0. M., 1975, Reconnaissance survey of the intermediate-level liquid waste transfer 1 ine between $X-10$ and the hydrofracture site, ORNL/TM-4783, $19 \mathrm{pp}$.

Duguid, J. 0., 1975, Status report on radioactivity movement from burial grounds in Melton and Bethel valleys, ORNL-5017, 64 pp.

Flaig, W., 1971, Characterization of humic substances by their physical and chemical properties, in Advances in Organic Geochemistry, Int. Ser. Monagram E. Sci., vol. 33, H. R. V. Gaertner and H. Wehner, eds., 49-67.

Ghassemi, M., and Christman, R. F., 1968, Limnol. Oceanog. 12, 583.

Grim, R. E., 1968, Clay Mineralogy, New York: McGraw-Hi11, 596 pp.

Holand, H. D., et al., 1964, On some aspects of the chemical evolution of cave waters, J. Geol. 72, 36-67.

Jackson, M. L., 1956, Soil Chemical Analysis-Advanced Course, published by the author, Wisconsin Univ., Madison, Wisconsin, 991 pp.

Jenne, E. A., 1968, Controls on $\mathrm{Mn}, \mathrm{Fe}, \mathrm{Co}, \mathrm{Ni}, \mathrm{Cu}$, and $\mathrm{Zn}$ concentrations in soils and water, in Chemistry Series No. 73, ACS, 337-387.

Jenne, E. A., and Wahlberg, J. S., 1968, Role of certain stream-sediment components in radio-ion sorption, USGS Prof. Paper 433-F.

Kee, N. S., and Bloomfield, C., 1967, The solution of some minor element oxides by decomposing plant materials, Geochim. Cosmochim. Acta $\underline{24}, 206-225$.

Kemp, A. L. W., and Wong, H. K. T., 1974, Molecular weight distribution of humic substances from Lakes Ontario and Erie sediments, Chim. Geol. 14, 15-22. 
Leland, H. V., and Shrimp, N. F., 1973, Factors affecting the distribution of lead and other trace elements in sediments of southern Lake Michigan, in Trace Metals and Metal-Organic Interactions in Natural Waters, P. C. Singer, ed., Ann Arbor Sci. Pub., 89-129.

Lomenick, T. F, Jacobs, D. G., Struxness, E. G., 1967, The behavior of ${ }^{\circ} \mathrm{Sr}$ and ${ }^{13} \mathrm{CS}$ in seepage pits around ORNL, Health Phys. 13, 897905.

Malcolm; R. L., et al., 1968, Conditional stability constants of a North Carolina soil fulvic acid with $\mathrm{Co}^{2+}$ and $\mathrm{Fe}^{3+}$, in Proc. Symp. Org. Matter in Natural Waters, D. W. Wood, ed., Inst. Marine Sci., Univ. of Alaska, $485 \mathrm{pp}$.

Murray, D. J., et a1., 1968, The adsorption of aqueous metal on colloidal hydrous manganese oxide, in Adsorption Form Aqueous Solutions, Adv. Chem. Ser., No. 79.

Murray, J. W., 1975a, The interaction of metal ions at the manganese dioxide--solution interface, Geochim. Cosmochim. Acta 39, 505-519.

Murray, J. W. 1975b, The interaction of cobalt with hydrous manganese dioxide, Geochim. Cosmochim. Acta 39, 635-647.

Norvel1, W. A., and Lindsay, W. L., 1969, Reactions of EDTA complexes of $\mathrm{Fe}, \mathrm{Zn}, \mathrm{Mn}$, and $\mathrm{Cu}$ with soils, SSSAP 33, 86-91.

Pickering, R. J., 1969, Distribution of radioactivity in Clinch River bottom sediment, USGS Prof. Paper 433-H, $25 \mathrm{pp}$.

Pickering, R. J., 1970, Composition of water in C1 inch River, Tennessee River, and White 0ak Creek as related to disposal of low-level. radioactive waste, USGS Prof. Paper 433-J.

Rashid, M. A., 1971, Role of humic acids of marine origin and their different molecular weight fractions in complexing di- and trivalent metals, Soil Sci. 111, 298-306.

Rashid, M. A., and King, L. H., 1969, Molecular weight distribution measurements on humic and fulvic acid fractions from marine clays of the Scotian Shelf, Geochim. Cosmochim. Acta 33, 147-151.

Rhodes, D. W., 1957, The effect of $\mathrm{pH}$ on the uptake of radioactive isotopes from solution by a soil, SSSAP $21,389-392$.

Schnitzer, M., and Skimmer, S. I. M., 1967, Organo-metallic interactions in soils: 7. Stability constants of $\mathrm{Pb}^{2+}, \mathrm{Ni}^{2+}, \mathrm{Co}^{2+}$, and $\mathrm{Mg}^{2+}$ fulvic acid complexes, Soil Sci. 103, 247.

Schwertmann, U., 1973, Use of oxalate for Fe extraction from soils, Can. J. Soil Sci. $53,244-246$. 
Sillen, L. G., and Martell, A. E., 1971, Stability Constants of Metal-Ion Complexes: Supplement No. 1, Chem Soc. (London) Spec. Pub. 17, 754 pp.

Sorathesn, A., Bruscia, G., Tamura, T., and Struxness, E. G., 1960, Mineral and sediment affinity for radionuclides, USAEC ORNL/CF$60 / 6 / 93,28 \mathrm{pp}$.

Szalay, A., 1963, Cation exchange properties of humic acids and their importance in the geochemical enrichment of $\mathrm{UO}_{2}^{++}$and other cations, 2nd Conf. of the Int. Union of Pure and Applied Chemistry.

Szalay, A., 1960, Accumulation of uranium and other micrometals in coals and organic shales and the role of humic acids in these geochemical enrichments, Arkiv for Mineralogi och Geologi, Band 5, 23-36.

Szalay, A., and Szilagyi, M., 1961, Investigations concerning the retention of fission products on humic acids, Acta Physica, Academiae Scientiarum Hungaricae, Tomas XIII, 421-436.

Tamura, T., 1963, Selective ion exchange reasctions for cesium and strontium by soil minerals, Coll. Int1. Sur la Retention et la Migration des Ions Radioactifs dans les Sols, Paris, Presses Universitaires de France, 95-104.

Tamura, T., 1965, Selective sorption reactions of strontium with soil minerals, Nuclear Safety $\underline{7}, 99-103$.

Truesdel1, A. H., and Jones, B. F., 1974, WATEQ, a computer program for calculating chemical equilibria of natural waters, J. Res. U. S. Geol. Surv. ?, 233-248,

Varga, J. A., and Jacobs, D. G., 1970, Dissolution of calcium-strontium carbonate and its subsequent movement in the ground, ORNL/TM-3130.

Wallace, A., and Lunt, 0. R., 1956, Reactions of some iron, zinc, and manganese chelates in various soils, SSSAP 20, 479-482. 


\section{Content of ${ }^{60} \mathrm{Co}$ in Shale and Soil}

Table Al is a compilation of ${ }^{60} \mathrm{Co}$ contents and $\mathrm{pH}$ of shale samples from various depths of the three wells (T7-8, T7-9, and T7-10) which were drilled approximately parallel to the strike of bedrock between trench 7 and the cobalt seep. Note that ${ }^{6}{ }^{\circ} \mathrm{Co}$ is the sole constituent; radionuclides such as ${ }^{137} \mathrm{Cs},{ }^{90} \mathrm{Sr},{ }^{106} \mathrm{Ru}$, and the transuranics are completely absent as they were in the ground water from these wells. Antimony-125 was not found in these soils even though a trace was detected in the water of T7-8. The ${ }^{60} \mathrm{Co}$ content of the shale is proportional to groundwater concentrations of the radionuclide from three locations (Tables Al and 1). The ${ }^{60} \mathrm{Co}$ concentrations in water are highest in T7-8 and decrease away from the trench toward T7-10, where only a trace has been measured. This suggests that adsorption kinetics are such that wherever ${ }^{\circ}{ }^{\circ} \mathrm{Co}-$ bearing ground water flows (which contains the radionuclide in association with a chelating agent), a certain amount of the radionuclide, proportional to its concentration in the ground water, is adsorbed by the shale. Consequently the shale along the principal route of ${ }^{6}{ }^{\circ} \mathrm{Co}$ migration from the trench to the seep should contain substantial ${ }^{60} \mathrm{Co}$ concentrations. In this light, the seep is not an area where organo- ${ }^{60} \mathrm{Co}$ complexes break down and release ${ }^{60} \mathrm{Co}$ for subsequent fixation in the soils. Rather, adsorption of ${ }^{60} \mathrm{Co}$ by soil and shale along its migration route is a matter of competition between the organic chelates in the water and adsorbing substrates in the shale and soil.

An unusual aspect of the data in Table $\mathrm{Al}$ is that large ${ }^{60} \mathrm{Co}$ concentrations in core T7-8 existed in the shale far above the water table, which was at a depth of about $24-25 \mathrm{ft}$ at this location when the well was drilled. In T7-9 and other sites to be discussed in the next section, ${ }^{60} \mathrm{Co}$ is predominantly confined to ground-water levels. The ${ }^{60} \mathrm{Co}$ concentration above the water table at well T7-8 was probably formed when a ground-water mount existed under the trench during its operation. Possibly related to this is a soft zone in the shale in well T7-8 at 10-14 ft. A similar soft zone occurs at approximately the same depth in well T7-9. However, contamination of this zone with ${ }^{60} \mathrm{Co}$ was not found.

The soft zone in well T7-8 appears to give witness to the earlier higher water table at this location during trench operation. Exchange of $\mathrm{Na}^{+}$onto clays from the $\mathrm{Na}^{+}-$rich radioactive wastes could have caused the soft zone, and ${ }^{60} \mathrm{Co}$ could have become fixed onto the shale at this time. This is also supported by the report that the water table at the site of trench 5 rose $10 \mathrm{ft}$ upon initial operation of the trench ( $W$. delaguna, 1962). The lack of ${ }^{60} \mathrm{Co}$ in the soft zone from core T7-9 argues against this origin of the soft layer, and perhaps it is a result of mineralogic heterogenetics in the shale. 
Table Al. Cobalt-60 concentration and $\mathrm{pH}$ of shale from wells drilled between trench 7 and the cobalt seep (June 1974)

\begin{tabular}{cccc}
\hline We1 & $\begin{array}{c}\text { Depth } \\
(\mathrm{ft})\end{array}$ & $\begin{array}{c}60 \\
(\mathrm{dpm} / \mathrm{g})\end{array}$ & $\mathrm{pH}^{*}$ \\
\hline T7-8 & 10.7 & $1.12 \times 10^{3}$ & 5.81 \\
& 12.7 & $9.85 \times 10^{3}$ & 8.86 \\
& 14.7 & $1.89 \times 10^{4}$ & 5.71 \\
& 16.7 & $1.61 \times 10^{4}$ & 5.78 \\
T7-9 & 18.7 & $1.35 \times 10^{4}$ & 9.22 \\
& 20.0 & $3.06 \times 10^{2}$ & 5.40 \\
& 22.1 & $1.18 \times 10^{3}$ & 5.40 \\
& 24.2 & $3.37 \times 10^{3}$ & 5.03 \\
& $25.4-25.8$ & $3.56 \times 10^{3}$ & 5.13 \\
& 28.0 & $2.75 \times 10^{3}$ & 5.08 \\
& 31.0 & $2.51 \times 10^{3}$ & 5.09 \\
& $33.0-34.0$ & $4.34 \times 10^{3}$ & 5.09 \\
& 18.0 & 41.3 & 4.79 \\
& $19-22$ & 24.1 & 5.08 \\
\hline
\end{tabular}

* Measured by equilibrating $5 \mathrm{~g}$ of soil with $5 \mathrm{ml}$ distilled water for $1 \mathrm{hr}$, centrifuging the soil, and reading the $\mathrm{pH}$ of the supernatant liquid. 
The $\mathrm{pH}$ of shale samples is correlated with ${ }^{60} \mathrm{Co}$ concentration (Table AT). The average pH of shale from core T7-8 is about 7.1 ; in T7-9 it is 5.2; and in T7-10 it 1s 4.95. Either the shale has obtained its high ph from buffering the $\mathrm{OH}^{-}$content of ground water flowing from the trench, or shale with a higher $\mathrm{pH}$ (originating from natural causes) adsorb more ${ }^{60} \mathrm{Co}$ than lower $\mathrm{pH}$ soils. Experimental data described in the earlier section suggest that greater adsorption occurs at low $\mathrm{pH}$, possibly because of increased dissociation of ${ }^{\circ}{ }^{\circ} \mathrm{Co}$ from its organic complexes. Therefore, contaminated soils probably derive their higher $\mathrm{pH}$ from adsorption of $\mathrm{OH}^{-}$from the waste solutions. This is consistent with the assertion in the previous section of this report that the Conasauga shale is effective in buffering the high $\mathrm{pH}$ of the waste.

A compilation of radioisotope contents and $\mathrm{pH}$ of soil samples from various depths of six cores which were drilled in an approximate semicircle around the west end of the cobalt seep is presented in Table $A 2$.

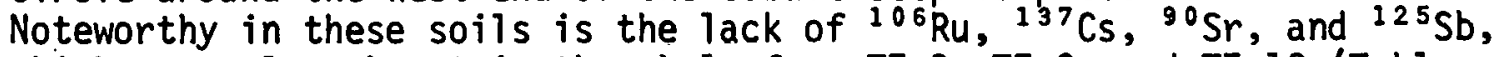
which were also absent in the shale from T7-8, T7-9, and T7-10 (Table A1).

Apparently these isotopes, which are expected to have composed a large portion of the radioactive waste delivered to this trench, migrate from the trench without significant uptake, or the isotopes are strongly fixed in the shale adjacent to the trench. The presence of ${ }^{125} \mathrm{Sb}$ in the ground water of T7-13 (Table AT) and its absence in the soils of that and all the other sites imply that migration without substantial sediment uptake is relevant for this radionuclide. However, the total absence of what in all probability were the principal radioactive constituents of the waste delivered to this trench, ${ }^{37} \mathrm{Cs}$ and ${ }^{90} \mathrm{Sr}$, in all the water and soils analyzed, is a strong suggestion for their effective retention by the Conasauga shale at their site of original deposition.

Alpha-emitting radionuclides, such as the transuranics, were detected in soils from wells RS7, T7-12, and T7-13 (Table A2). Concentrations as $\mathrm{high}$ as $140 \mathrm{dpm} / \mathrm{g}$ are found in the soil from well T7-13. The only specific alpha-emitting radionuclide identified in the seep soil to date is ${ }^{238} \mathrm{Pu}$ ( $T$. Tamura, personal communication). Plutonium is reported to be very immobile in soils, especially in the $\mathrm{pH}$ range of 2.2-8.4 (Rhodes, 1957). Adsorption of plutonium by soils is reported to be almost irreversible. The mobility of plutonium in this study as reflected by its apparent migration from the trench may be attributed to complexation with strong chelating agents, possible the same as those involved in ${ }^{6}$ Co mobilition.

As discussed previously, ${ }^{60} \mathrm{Co}$ concentrations in soils and ground water can be employed to estimate ${ }^{60} \mathrm{Co}$ transport direction from the trench to the seep. As observed in the shale from the cores taken between the trench and the cobalt seep (Table AT), ${ }^{\circ} \mathrm{Co}$ concentrations in the shale from wells in the vicinity of the seep approximately correlate to ${ }_{60}^{\circ} \mathrm{Co}$ contents of ground water from those wells (Tables A1, A2 and 1). The highest ${ }^{\circ} \mathrm{Co}$ in soils comes from wells RS7, T7-12, and T7-13, which 
Table A2. Cobalt-60 concentration, total- $\alpha$ concentration, and $\mathrm{pH}$ of soils from wells drilled near the cobalt seep (June-August 1974)

\begin{tabular}{|c|c|c|c|c|}
\hline We11 & $\begin{array}{l}\text { Depth } \\
\text { (in.) }\end{array}$ & $\begin{array}{l}\text { Total } \alpha \\
\text { (dpm/g) }\end{array}$ & $\begin{array}{l}{ }^{60} \mathrm{Co} \\
(\mathrm{dpm} / \mathrm{g})\end{array}$ & $\mathrm{pH}$ \\
\hline \multirow[t]{4}{*}{ RS7 } & $0-3 *$ & 26.4 & $4.95 \times 10^{4}$ & 7.60 \\
\hline & $3-12$ & 18.6 & $4.37 \times 10^{4}$ & 7.37 \\
\hline & $12-18$ & 19.6 & $2.67 \times 10^{4}$ & 7.12 \\
\hline & $18-27$ & 9.6 & $8.43 \times 10^{3}$ & 7.02 \\
\hline \multirow[t]{3}{*}{$T 7-11$} & 6 & --- & $1.69 \times 10^{4}$ & 5.83 \\
\hline & 18 & $\cdots$ & $1.12 \times 10^{4}$ & 6.33 \\
\hline & $30 \star$ & --- & $1.29 \times 10^{4}$ & 6.81 \\
\hline \multirow[t]{4}{*}{ T7-12 } & 4 & --- & 20.6 & 4.64 \\
\hline & 16 & -- & $1.62 \times 10^{2}$ & 4.68 \\
\hline & $28 *$ & 75.0 & $2.86 \times 10^{4}$ & 7.44 \\
\hline & 40 & $\therefore$ & $4.91 \times 10^{3}$ & 7.77 \\
\hline \multirow[t]{7}{*}{$T 7-13$} & $45-50$ & --- & 9.84 & 5.19 \\
\hline & $50-55$ & --- & $8.83 \times 10^{2}$ & 5.67 \\
\hline & $64-68 *$ & 89.0 & $2.45 \times 10^{4}$ & 8.50 \\
\hline & $72-78$ & 135.6 & $1.44 \times 10^{4}$ & 9.10 \\
\hline & $78-85$ & 138.6 & $1.63 \times 10^{4}$ & 8.72 \\
\hline & $91-95$ & --- & $6.37 \times 10^{3}$ & 7.75 \\
\hline & $97-102$ & 52.0 & $4.70 \times 10^{3}$ & 9.16 \\
\hline \multirow[t]{4}{*}{$T 7-14$} & 8 & -.- & $4.77 \times 10^{2}$ & 5.96 \\
\hline & 20 & --- & $4.87 \times 10^{3}$ & 5.58 \\
\hline & $32^{\star}$ & --- & $6.66 \times 10^{3}$ & 6.42 \\
\hline & 44 & -- & $2.98 \times 10^{3}$ & 6.20 \\
\hline \multirow[t]{3}{*}{$T 7-15$} & 8 & --- & 22.0 & 5.22 \\
\hline & 26 & --- & $7.08 \times 10^{2}$ & 5.62 \\
\hline & $44^{\star}$ & -- & $1.06 \times 10^{3}$ & 5.97 \\
\hline
\end{tabular}

*Denotes the approximate level of the water table at the time of sampling. 
lie in a line pointing approximately to the middle of the trench. The ${ }^{60} \mathrm{Co}$ concentrations greatiy decrease in soils to the north of this line in samples from $T 7-14$ wells and T7-15, and also slightly decrease to the south in well T7-11 (Table A2).

This distribution of ${ }^{60} \mathrm{Co}$ in seep soils, together with analyses of shale between the trench and the seep, supports the assumption that the main route of recent ${ }^{60} \mathrm{Co}$ migration from the trench to the seep occurs on a line through wel1s $77-3$ and $T 7-13$ and the seep. This general direction of ground-water flow is about perpendicular to the topographic contours of the area, and deviates from the strike of the Conasauga shale by about $20^{\circ}$.

Comparison of the $1974{ }^{60} \mathrm{Co}-\mathrm{soil}_{\mathrm{l}}$ data with Duguid's data (1975, p. 9) collected in 1973 reveals that fixed ${ }^{60} \mathrm{Co}$ concentrations in seep soil decreased significantly during the one-year period. In May and June $1973,{ }^{60}$ Co concentrations in the top layer of seep soil were $7.2 \times 10^{5}$ and $1.2 \times 10^{5} \mathrm{dpm} / \mathrm{g}$, respectively. In September 1973 , the concentration had decreased to $8.5 \times 10^{4} \mathrm{dpm} / \mathrm{g}$; and in June 1974 , only $5.0 \times 10^{4} \mathrm{dpm} / \mathrm{g}$ was detected denoting approximately a tenfold decrease from its concentration 13 months before. This decrease in ${ }^{60} \mathrm{Co}$ concentration greatly exceeds that which would result solely from radioactive decay $\left({ }^{60} \mathrm{Co}\right.$ having a half-life of 5.2 years). Apparently the amount of radionuclide being removed from seep soils is greater than that being adsorbed from ${ }^{60} \mathrm{Co}$-bearing waters being supplied to the area. The amount of ${ }^{60} \mathrm{Co}$ in seep water decreased about one-third from June 1973 to June 1975 (Duguid, 1975; and Table A1, this report). Perhaps the amount of ${ }^{60} \mathrm{Co}$ in a chemical form suitable for adsorption has also decreased during this period.

Cobalt-60 concentrations in seep soils are generally highest in zones at or below the water table at the time of sampling (Table A2), though substantial ${ }^{\circ} \mathrm{Co}$ concentrations exist in some cores several feet above this level. Fluctuations in the water table of this area are a likely explanation for this occurrence. Rise of ground-water fluids through capillary action may al so occur. 


\section{THIS PAGE}

WAS INTENTIONALLY

LEFT BLANK 
ORNL/TM-5348

Distribution Category UC-70

INTERNAL DISTRIBUTION

1. R. G. Affel

2-9. S. I. Auerbach

10. E. A. Bondietti

11. F. T. Binford

12. J. A. Cox

13. F. L. Culler, Jr.

14. R. C. Dahlman

15. G. J. Dixon

16-30. J. 0. Duguid

31. L. D. Eyman

32. C. W. Francis

33. C. W. Gehrs

34. J. R. Gissel

35. D. R. Jackson

36. D. G. Jacobs

37. S. V. Kaye

38. E. M. King
39. L. C. Lasher

40. S. E. Lindberg

41. Herman Postma

42. D. E. Reichle

43. C. R. Richmond

44. R. A. Robinson

45. 0. M. Sealand

46-47. E. G. Struxness

48-49. Tsuneo Tamura

50. R. R. Turner

51. E. J. Witkowski

52-54. Central Research Library

55. Document Reference Section

56-60. Laboratory Records Department

61. Laboratory Records, ORNL-RC

62. ORNL Patent Office

\section{EXTERNAL DISTRIBUTION}

63. F. P. Baranowski, Director, Division of Nuclear Fuel Cycle and Production, Energy Research and Development Administration, Washington, DC 20545

64. G. H. Daly, Division of Nuclear Fuel Cycle and Production, Energy Research and Development Administration, Washington, DC 20545

65. E. H. Hardison, Energy Research and Development Administration, Oak Ridge Operations, Oak Ridge, TN 37830

66. George Hughes, Hydrology and Monitoring Section, Water Resources Branch, Ontario Ministry of The Environment, $135 \mathrm{St}$. Claire Avenue, Toronto, Ontario MAV IP5, Canada

67. Cyrus Klingsberg, Atlantic Richfield Hanford Company, Box 250, Richland, WA 99352

68. Research and Technical Support Division, Energy Research and Development Administration, Oak Ridge Operations, Oak Ridge, TN 37830

69. J. L. Liverman, Director, Division of Biomedical and Environmental Research, Energy Research and Development Administration, Washington, DC 20545

70-84. J. L. Means, Department of Geological and Geophysical Sciences, Princeton University, Princeton, NJ 08540

85. R. V. Ruhe, Director, Water Resources Research Center, Indiana University, Bloomington, IN 47401 
86. J. H. Rust, Department of Radiology and Pharmicology, University of Chicago, Box 144, 950 E. 59th Street, Chicago, IL 60637

87. J. L. Schreiber, Energy Research and Development Administration, Oak Ridge Operations, Oak Ridge, TN 37830

88. J. G. Steger, Division of Nuclear Fuel Cycle and Production, Energy Research and Development Administration, Washington, DC 20545

89. W. R. Coight, Division of Nuclear Fuel Cycle and Production, Energy Research and Development Administration, Washington, DC 20545

90. D. A. Webster, U. S. Geological Survey, Building 3504, ORNL.

91-336. Given distribution as shown in TID-4500 under category UC-70, Nuclear Waste Management. 